\title{
Can we mitigate the effect of natural disasters on child health? Evidence from the Indian Ocean tsunami in Indonesia
}

\author{
October 23, 2020
}

\begin{abstract}
The 2004 Indian Ocean tsunami was an international natural disaster unlike any seen before, killing 166,561 people in Aceh province, Indonesia. It prompted an unprecedented humanitarian response and was a catalyst in ending almost 30 years of civil conflict in Aceh. Since the tsunami was followed by a multitude of events, we first conduct a systematic review to identify those events in Indonesia. We then use a synthetic control method to estimate the combination of those effects on child mortality indicators in Aceh for the 13 years that followed the disaster using data from 258,918 children born between 1990 and 2017. The results show a significant increase in under-5 mortality only the year after the tsunami and no effect in the medium term. However, younger and older children were affected differently in the medium term. In fact, we show a decrease in child mortality among children aged 1-4 years. In contrast, we observe an increase in mortality among children under-1 in 2009 and 2010. Overall, the resilience of Aceh province points to the importance of coordinated international disaster responses after natural disasters.
\end{abstract}

Key Words: Natural disaster, child mortality, 2004 tsunami, synthetic control.

Classification Codes: I100, I120, I150, C21, C22, H84

\section{Highlights:}

1. The tsunami led to a statistically significant increase in under-5 mortality only the year that followed the disaster

2. The tsunami led to a significant reduction in child mortality among children aged 1-4 in the medium term 
3. Under-1 mortality increased significantly five years after the tsunami

\section{Introduction}

Individuals in low-income countries are exposed to different types of exogenous shocks. Among such shocks, the least studied and most likely to affect people lives in the long term are natural disasters. As a matter of fact, each year there are over 300 natural disasters globally with millions of victims that cost economic losses near USD $\$ 100$ billion (Yehuda, 2002). With the likely future rise in climate variation, and thus an increase in the intensity of natural disasters, understanding the mechanisms that allows the mitigation of the impact of natural disasters on population health is vital. Because the most vulnerable groups are disproportionally affected by natural disasters globally, such shocks can leave permanent impacts on health, hence reinforcing the intergenerational transmission of poverty. Recent evidence suggests that natural disasters affect well-being more than asset losses (Hallegatte et al., 2016) and that the occurrence of these shocks in utero and in early childhood is considered to be especially harmful because of their long lasting effect (Walker et al., 2005, Hoddinott et al., 2008, Gertler et al., 2014, Maluccio et al., 2009, Neelsen and Stratmann, 2011, Gluckman et al., 2008). Despite this, there is limited evidence of the effect of natural disasters on child health (Caruso and Miller, 2015, Chen et al., 2016, Maccini and Yang, 2009, Datar et al., 2013, Frankenberg et al.).

Several studies have aimed to identify the causes of mortality in natural disasters (Frankenberg et al., 2011, Gutierrez et al., 2005), but only a few have investigated the prolonged effects of natural disasters on mortality. Ho et al. (2017) use longitudinal data from households living in affected Indonesian provinces to estimate adult mortality and its causes the five years that followed the 2004 Tsunami. The results do not show strong evidence of an increase in adult mortality among residents in tsunami-affected communities. In Armenia, Armenian et al. (1998) showed that the earthquake led to an increase in adult mortality the first 6 months and to an increase in heart disease, while Nakagawa et al. (2009) find that there was an increase in acute myocardial infarction the three years that followed the Niigata-Chuetsu earthquake in Japan. Aida et al. (2017) provide evidence that mortality increases up to 38 months after the 2011 Japanese tsunami, especially among survivors with no social connections.

Our paper makes an important contribution to the literature on the effect of natural disaster 
on mortality by providing the first evidence of the prolonged effects of a severe natural disaster on mortality of children under-5. To do so, we focus on events caused by the largest earthquake recorded in over 40 years, which occurred on the $26^{\text {th }}$ of December 2004 in the Indian Ocean off the Northwest coast of Indonesia. The ensuing tsunami caused killed 167,540 persons in Indonesia, where most of the damages occurred in Aceh province, including 129,775 deaths and 36,786 people reported missing, i.e., almost $5 \%$ of Aceh's population. On the $28^{\text {th }}$ of March, 2005 a magnitude 8.6 earthquake struck off of Nias Island in neighbouring North Sumatra province further displacing many Acehnese. The tsunami also destroyed the local economy, where losses were estimated to be USD $\$ 4.45$ billion, or 97\% of Aceh's GDP in 2003 (World Bank, 2005). Structurally, one third of roads, schools and health facilities in Aceh were damaged (Athukorala and Resosudarmo, 2005). Lastly, the tsunami killed many local healthcare staff which led to decreased local capacity to care for the large influx of injuries and illnesses caused by the tsunami.

The tsunami also led to some effects that could have been beneficial to child mortality reduction. In response to this human and economic devastation, the international community generated an unprecedented humanitarian response. In total, USD $\$ 7.7$ billion was committed for relief and reconstruction by the government, non-governmental organizations and international donors (Masyrafah and McKeon, 2008), which represents the largest influx of aid in history. More specifically, aid was aimed to prevent "second mortality" post disaster through various direct channels such as to prevent communicable diseases outbreak (Athukorala, 2012) and to develop effective policies for sustainable reconstruction. In addition, the devastation was so severe that it further encouraged Aceh's separatists and the Indonesian military to sign a peace agreement that ended a 30-year conflict. At the same time, Aceh strengthened its Islamic identity. Posttsunami relief efforts ushered in Islamic organizations that did not previously have a presence in Aceh. These organizations helped to intensify the practice of Sharia law and intensified religious zeal (Ichwan, 2011). As a result, the subsequent effects of the tsunami on child mortality may be both positive and negative.

Our paper aims to investigate whether the combination of the different effects of the tsunami translated into an increase in subsequent child mortality the years that followed the catastrophe. Indeed, while international relief organizations played an important role in health services delivery, it is not clear if these efforts were sufficient to prevent subsequent child mortality. To 
answer this question, we first conduct a systematic review to identify the multiple short term and longer term effects of the tsunami in Aceh province on child health. Then, we estimate the effect of the tsunami on child mortality the 13 years that followed the natural disaster. To do so, we use non-affected Indonesian provinces to create a synthetic Aceh province using the synthetic control method pioneered by Abadie et al. (2010). Our results show that the tsunami led to a significant increase in under-5 mortality in 2005, the year that followed the catastrophe but did not have any longer term impacts. We however also provide evidence that different age groups were not affected at the same time by this natural disaster in the medium term. More precisely, we show that although children aged 1-4 were negatively affected by the disaster immediately, child mortality for children aged 1-4 decreases in the medium term. Conversely, in addition to the immediate increase in infant mortality, we also observe that mortality of children under-1 also increases 5 years after the tsunami.

The remainder of the paper is organised as follows: Section 2 reviews the literature on the short-term and longer-term effects of the tsunami in Indonesia. Section 3 describes the data and empirical approach used. Section 4 presents the results and robustness checks, while Section 5 discusses findings. Finally, Section 6 concludes.

\section{Immediate and longer term effects of the tsunami on child health: a systematic review}

The Asian tsunami that hit Aceh was followed by a multitude of events that may have had a combination of negative and positive longer-term effects on child mortality. In order to provide evidence of those transmission channels, we conduct a systematic review. Exact search terms, syntax and database search results are included in Appendix 1. After the review of these search results, a snowballing approach was used to capture articles from reference lists of extracted literature. An additional search of google scholar was conducted to capture grey literature, reports from international relief and governance agencies and unpublished $\mathrm{PhD}$ dissertations. Seventy-eight full-text articles written in English met the inclusion criteria and were included in the review. A description of these papers is presented in Appendix 2. 


\subsection{Negative impacts of the tsunami on child mortality}

The tsunami severely damaged health infrastructures. Five of 27 hospitals, 19 of 237 large public health centers and one third of village birth clinics and village health centers in Aceh were destroyed, leaving a limited local capacity to attend to the influx of medical needs (World Bank, 2005). Data from the Study of the Tsunami Aftermath and Recovery (STAR) estimate the disruptions in service provision in 2005 and 2006 in heavily damaged communities to be $64 \%$ for community health posts, $49 \%$ for village midwives and $63 \%$ for public health centers, while emergency primary health care services were only established in $31 \%$ of those communities (Frankenberg, 2007). The World Health Organization (2005) reports that of the 497 provincial health staff in Aceh, 57 died and 59 were reported missing after the tsunami. Additionally, 53 of the 244 health facilities were destroyed or incapacitated. Moreover, the proportion of health facility staff who died is estimated to be $22 \%$ in heavily damaged communities by the STAR project. Importantly, this lack of health infrastructure prompted a delay in seeking care and increased morbidity since patients were unable to get the immediate care they needed (Guha-Sapir et al., 2007, Pascapurnama et al., 2016, Redwood-Campbell and Riddez, 2012). In addition, there was a decrease in the quality of care reported in public health centres since $17 \%$ of affected sub-districts reported a decrease in the quantity of health workers, $20 \%$ reported a decrease in supply of pharmaceuticals, and a $18 \%$ decrease of equipment, sterile treatment conditions, and inadequacy of waters and toilets. It may be worth noting that the destruction of health infrastructures and the deaths of health workers may have a large detrimental impact on infants and children mortality given that in Indonesia, and more generally in low-and middle income countries, health facilities primarily function as providers of maternal and child care.

The disaster also destroyed vital water and sanitation infrastructure leaving large displaced populations at an increased risk of disease. Post-tsunami, diarrhoea was found to be the second leading cause of morbidity and pointed to the need for improved systems (Gupta et al., 2007).

The tsunami destroyed transportation infrastructure, agricultural production and coastal fishing, which had a dramatic impact on already impoverished communities. The market for fish collapsed because of damage to harbors and public fears of water contamination. Food prices increased because of the destruction of agricultural lands and farm costs rose because of scarce resources and large transportation cost of obtaining new equipment due to the destruction of 
roads (Webb, 2005). Thorburn (2009) notes that in the four years before the tsunami, the poverty rate doubled in Aceh to nearly $30 \%$ and the tsunami pushed thousands more families into poverty. The study found that although aid programs brought much needed livelihood support and restored many of these families back to work within a year, newly developed enterprises, micro-credit formed businesses and co-operative community development programs could not alleviate pre-existing vulnerability.

Changes to society and culture also occurred after the disaster. Post-tsunami Aceh strengthened its Islamic identity (Shah and Cardozo, 2014). More specifically, Islam was heavily used post-disaster to teach about the relationship between natural phenomenon and faith in order to strengthen religious beliefs (Adiyoso and Kanegae, 2013). Tsunami relief ushered in new, extreme forms of Islamic ideology from radical organizations that developed a presence and a following in the province during their humanitarian aid work (Ichwan, 2011). The increased conservative Islamic values displayed in Aceh after the tsunami may have given rise to further reduction in health seeking behaviours among women and their children.

Finally, the presence of international NGOs' and funding agencies often leads to a lack of local capacity to respond to future sustainability and vulnerability reduction needs. In Aceh, the large influx of organizations overpowered local voices and led to many instances of corruption, unsustainable skyrocketing cost for local materials and wage competition that pushed local labour out of the reconstruction market (Jayasuriya and McCawley, 2010, Jayasuriya and McCawley, 2008). There was no evidence of aid crowding out local government budgets (Athukorala and Resosudarmo, 2005), however, potential shifts in government spending because of earmarked health aid could have had a negative effect on health after aid organizations reduced their local presence and turned over health system management to local staff.

\subsection{Positive impacts of the tsunami on child mortality}

Within the relief aid effort, USD $\$ 700$ million was committed specifically for health-focused work from 135 health NGO's, 16 donors and 152 international actors (Masyrafah and McKeon, 2008). In total there were 330 health projects and $85 \%$ of these projects were conducted by NGOs (Masyrafah and McKeon, 2008). The allocation of aid funds took place mainly the four years that followed the tsunami were programmed to be disbursed by 2008. As a matter of 
fact, by end 2007, 88 percent (US $\$ 6.8$ billions) of committed aid had been allocated to specific projects (Jayasuriya and McCawley, 2010, Jayasuriya and McCawley, 2008). Health aid improved the capacity of the local health system through rebuilding destroyed and damaged health and sanitary infrastructures and training local medical staff (World Health Organization, 2015). Lee et al. (2014) studied the impact of aid to create durable development solutions one and six year post-tsunami and found housing quality, water, sanitation, and perceptions of local and national health services all improved by 2011.

Chang-Seng (2013) argues the tsunami prompted governance change along with rapid decentralization and facilitated the reorganization of government. Indeed, $90 \%$ of the capital city, Banda Aceh, was destroyed by the disaster and $40 \%$ of its government staff were killed (World Health Organization, 2015). Total destruction of this governance hub allowed for the influence of international actors, with aid and political pressure as tools for incentivizing change, to rebuild systems of governance in partnership with the Indonesian central government. In 2014 universal social health insurance was introduced in order to achieve universal health coverage by 2019 (World Health Organization, 2017). While it is complicated to infer that international scrutiny causes further decentralization and prompted the introduction of social health insurance, one can assume that the increased attention given to Indonesia in the disaster response and recovery effort shifted governance towards improving health systems more than what would have been done in the absence of the tsunami.

Lastly, the "building back better" reconstruction plan focused on sustainable re-development and both rebuilt destroyed capital and made more productive use of capital post-tsunami (Heger, 2016). From 2005-2009 in Banda Aceh, reconstruction doubled built up areas with less dense settlements, enhanced costal development and infrastructure improvements (Achmad et al., 2015). In addition to rebuilding and improving economic systems locally, Aceh province reopened to international investors, which recreated trade connections to Malay and Islamic worlds and generated pathways to future growth (Phelps et al., 2011). Heger (2016) finds strong evidence of a creative-destruction effect of the tsunami that facilitated short and long-term economic growth in Aceh above what was seen in other Indonesian provinces. Economic growth and opportunity is tied to poverty alleviation and could influence many of the social determinants of health that could have lasting effects on population health. 
Finally, the tsunami ended an almost 30-year civil conflict that cut off Aceh province from the rest of the country. The civil conflict killed over 15,000 people, shut off access to education and health systems and left nearly 1.4 million people displaced (Worldwatch Institute). The cost of the conflict was estimated at USD $\$ 10.7$ billion (World Bank, 2009b). Peace talks had begun in secret prior to the tsunami, however, the tsunami was a catalyst in resuming peace talks in order to help Aceh receive international aid and give the rebel group local political legitimacy in the rebuilding process. Upon signing the 2005 peace agreement, the Free Aceh Movement or Gerakan Aceh Merdeka (GAM) gave up their claim for independence and negotiated more autonomy for Aceh in terms of receiving central government funds (Gaillard et al., 2008a). The peace agreement allowed for improvements to local systems and infrastructure, increased international aid and improved local governance (Beardsley and McQuinn, 2009). The ending of the civil conflict undoubtedly had a positive impact on short-term health and it would be expected that improved access to services and outside resources would improve health over time.

\subsection{Undetermined impact of the tsunami on child mortality}

There is some evidence in the literature that maternal posttraumatic stress disorder is detrimental to child mental health (McFarlane, 1987, Pfefferbaum, 1997). It is clear that the tsunami led to a decline in mental health among survivors, especially in women and young adults (Frankenberg et al., 2008) and that this decline affected long-term health of survivors (Rassekh and Santosham, 2014). However, the tsunami was also a catalyst towards developing a mental health system (Marthoenis et al., 2016). Before the tsunami, there was only one 250-bed mental health hospital available in Aceh and little common knowledge of mental health conditions (De Jong et al., 2005, Meilianda et al., 2017). After the tsunami, intensive training for general practitioners and other aid efforts led to improved capacity, care coordination, and support of mental health services that otherwise would not have been available (Prasetiyawan et al., 2006). It is unclear, however, if the tsunami could have had an effect on the mortality of children born from mothers who survived the tsunami through the mental health channel. 


\section{Methods}

\subsection{Data}

We use the Indonesia Demographic and Health Survey (DHS) data, collected in 1997, 2007, 2012 and 2017. These data come from nationally representative cross-sectional surveys and contain information on child death and on several intermediary child health outcomes. We used birth record from DHS to estimate mortality indicators. This dataset has one record for every child ever born to interviewed women. Essentially, it contains the full birth history of all women interviewed for all children born in the last 5 years ${ }^{1}$. It includes information on year of birth, on whether the child is alive at the time of the interview and if the child is dead, the age at death. As a result, unlike the use of birth and death registers, our measures of child mortality are unlikely to depend on the quality of registration services. Using information on the province where the household lives and on the date of birth and death, we reconstruct birth cohorts from 258,918 born between 1990 and 2017 (Appendix 3) and estimate indicators per province and year. Among the 258,918 children included in our cohort, 88,164 children are under-5 years old at the time of the interview. We use the cohort of 258,918 children to estimate annual child mortality rates by province (Masset, 2015) and the cohort of the 88,164 children to estimate the effect of the tsunami on main causes to child mortality.

The primary health outcome is under-5 mortality per 1,000 live births, but we also investigate the distribution of under-5 child mortality at different periods: infant (under-1) and 1-4 years. We do so because these different mortality indicators are unlikely influenced by the same factors (Muldoon et al., 2011). Infant mortality is good marker of the quality of care, while mortality of older children is mainly caused by environmental factors such as political and medical infrastructure, poor access to clean drinking water, and lack of sanitation. We also use DHS data in order to estimate the effect of the tsunami on the main factors of child mortality. To identify relevant factors of deaths among children under-5, we use data from the Institute of Health Metrics and Evaluation (IHME) ${ }^{2}$ on the causes of death in Indonesia. Note however that unlike mortality rates, information on intermediary outcomes are only asked for children under5 hence the period covers ranges from 1992 to 2012 with an interruption between 1997 and 2002.

\footnotetext{
${ }^{1}$ Note that the data set collected in 1997 contains this information for all children born.

${ }^{2}$ Global of Disease compare tool: https://vizhub.healthdata.org/gbd-compare/
} 
Lastly, we present the effect of the tsunami on the other transmission channels identified in the literature review. To do so, we use data from the Indonesia Database for Policy and Economic Research (World Bank, 2015) that contain province-level information $(\mathrm{n}=33)^{3}$ on fiscal, economic, infrastructure, social and demographic indicators over the period 1976-2014. The data set combines data from the Indonesian Central Bureau of Statistics, Ministry of Finance, and Central Bureau of Statistics special reports and primarily collected data by the World Bank. Vital system access measures include the percentage of households with access to safe water ${ }^{4}$ and safe sanitation ${ }^{5}$ and were based on the National Socioeconomic Survey. Information was available between 1996 and 2013 but was missing in 2000, 2001, 2002, and 2005 .

\subsection{Empirical Strategy}

A naive analysis consisting of a direct comparison of health outcomes in Aceh to those observed in other Indonesian provinces would be misleading given that Aceh was distinctly different from the rest of Indonesia given its long history of civil conflicts, its limited geographical access and its high poverty level (Fan, 2006). As a result, the rest of Indonesia is not a valid counterfactual as highlighted by the differences in the trend in child mortality Figure $1^{6}$. However, recreating a synthetic Aceh is an attractive option since other provinces shared similar characteristics. We can see that given the geography of Indonesia, many others provinces are remote. In addition, Aceh has never been the poorest province of Indonesia. Finally, the Indonesian provinces of Maluku, Kalimantan, Central Sulawesi, West Timor and Papua were also been affected by communal conflicts prior 2004 .

\footnotetext{
${ }^{3}$ INDO-DPER lists 34 provinces, however, seven were created after 2000 (Bangka Belitung, Riau islands, Banten, Gorontalo, West Sulawesi, North Maluku, West Papua) and one was created after the period covered by our analysis (Kalimantan Utar). In addition, one province (East Timor) became independent in 1999 and was dropped from DHS 1997.

${ }^{4}$ Safe water includes access to bottled water, refill water, tap water, protected well more than 10 meters from a septic tank and protected spring located more than 10 meters from a septic tank.

${ }^{5}$ Safe sanitation means that each household had access to a private toilet and did not use a shared or public toilet.

${ }^{6}$ Note that on the graphs presented, we observe a peak in child mortality in 2001 that is particularly severe for children aged 1-4 years old. This peak in mortality is due to the civil conflict that was taking place in Aceh and that was particularly severe this year (Freeman \& Than, 2002)
} 
Figure 1: Trend in child mortality in Aceh and rest of Indonesia

Under-5 mortality (per 1,000 live births)

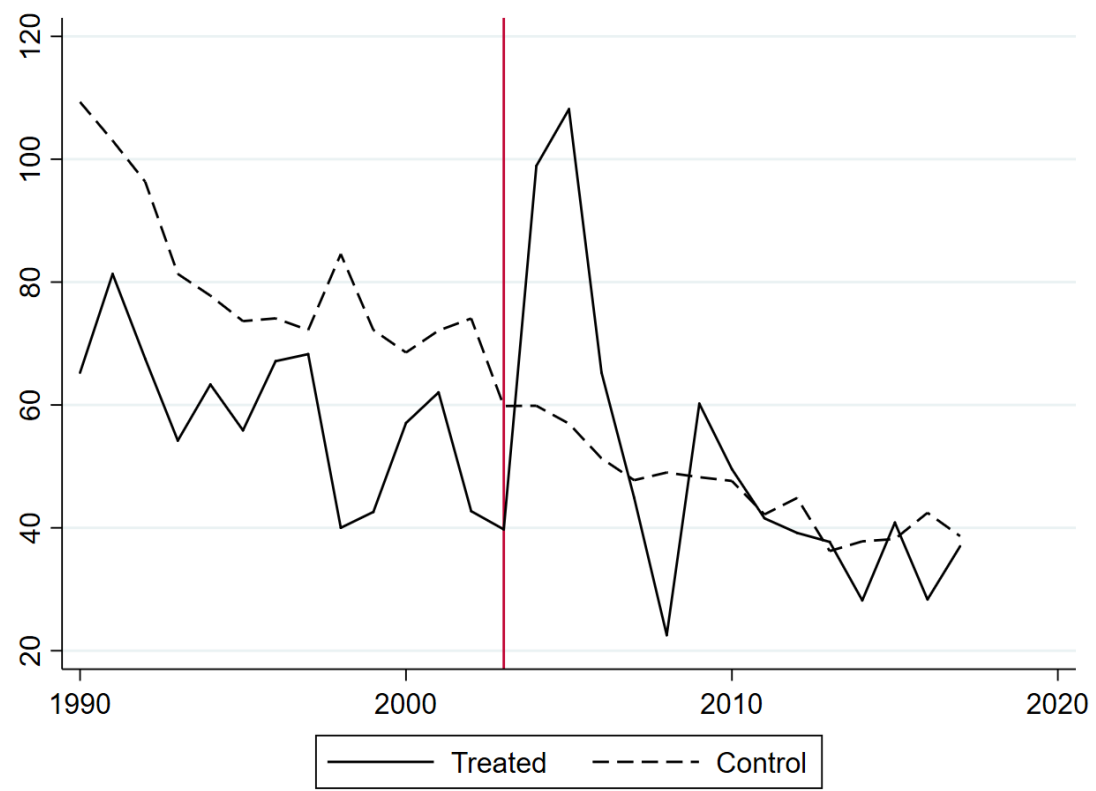

Under-1 mortality (per 1,000 live births)

1-4 years old mortality (per 1,000 live births)
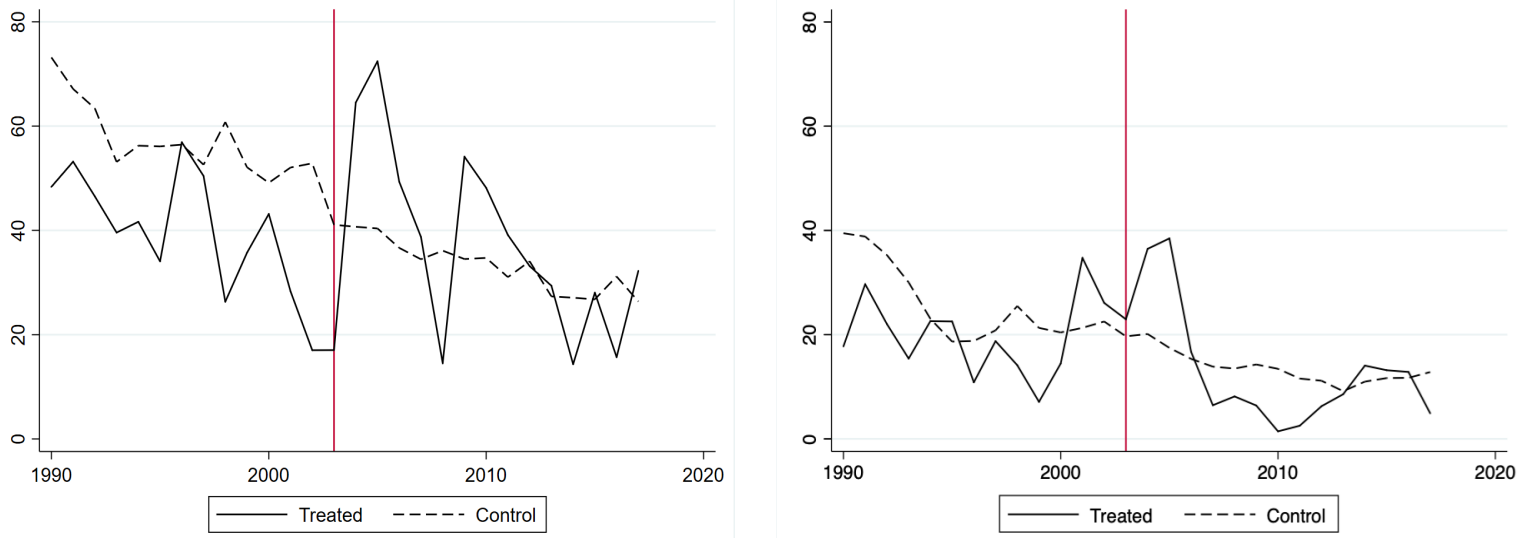

Instead, in order to reconstruct a valid counterfactual we employ the synthetic control method introduced by Abadie and Gardeazabal (2003) and Abadie et al. (2010). The synthetic control method involves constructing a counterfactual, the synthetic control, for the treated province, Aceh, by taking the weighted average of the unaffected provinces that minimises the root mean squared prediction error (RMSPE). For each outcome, a synthetic Aceh is created so that its pre-tsunami outcome trend mimics the one observed in Aceh province. The effect of the tsunami on child mortality is estimated by comparing the level of outcome in Aceh to the one observed in synthetic Aceh post-tsunami. 
There are many advantages of the synthetic control method over others quasi-experimental designs. Unlike matching, the synthetic control is a combination of control units, which provides a better comparison group for the treated unit than a single unit alone. Secondly, because the counterfactual is constructed by using all pre-tsunami years, the method, unlike difference-indifferences, accounts for unobserved heterogeneity that is time-varying (Abadie et al., 2010). In addition, the method allows to assess visually the quality of the counterfactual constructed by looking at the actual discrepancy between the treated unit and the combination of untreated units that provides the counterfactual (Abadie, 2019).

In keeping with the Abadie et al. (2010) model, let the observed outcome for province $i$ in year $t$ be defined as $Y_{i t}$. We define the outcome in province $i$ that has been impacted by the tsunami as $Y_{i t}^{I}$. We define the outcome for province $i$ that have not been impacted by the tsunami as $Y_{i t}^{N}$. If there are $J$ provinces not affected by the tsunami, potential synthetic controls, W, would be a weighted sum of control provinces such that $(J \times 1)$ weighting W $=\left(w_{2}, \ldots, w_{J+1}\right)^{\prime}$, where $w_{j}$ is the contribution of each control province to the synthetic Aceh with a positive weight. Note that all of the weighted contributions of control provinces sum to 1 .

For this analysis we are concerned with the effect of the tsunami on province $i$ at year $t$ which we will identify as $\alpha_{i t}$. Therefore, the effect of the tsunami for province $i$ at year $t>T_{0}$ can be defined as $\alpha_{i t}=Y_{i t^{-}}^{I} Y_{i t}^{N}$ given that $T_{0}$ represents all years before and including 2004. Because $Y_{i t}^{I}$ is observed for Aceh, $i=1$, to estimate $\alpha_{i t}$ we simply need to estimate $Y_{i t}^{N}$.

The synthetic control method choses weights of these donor provinces such that the distance between pre-intervention characteristics and outcomes for the treated district, Aceh $\left(X_{1}\right)$, and for the donor districts $\left(X_{0}\right)$ is minimized. Therefore, the synthetic control for unit $i$ is:

$\hat{Y}_{1 t}^{N}=\sum_{j=2}^{j=J+1} w_{j}^{*} Y_{j t}$ for $t>T_{0}$

And the effect of the tsunami for Aceh, $i=1$, is $\widehat{\alpha}_{1 t}=Y_{1 t}-\hat{Y}_{1 t}^{N}$.

Since the synthetic control model minimizes the distance between pre-intervention characteristics and outcomes, the optimal vector $\mathrm{W}^{*}$ is chosen such that the distance between $X_{1}$ and $X_{0} \mathrm{~W}$ is minimised, where $\mathrm{V}$ minimizes the RMSPE denoted $\overleftarrow{s_{1}}$ : 
$\left\|X_{1}-X_{0} W\right\| \mathrm{v}=\sqrt{\left.X_{1}-X_{0} W\right)^{\prime} V\left(X_{1}-X_{0} W\right)}$

Sometimes covariates are included in both $X_{1}$ and $X_{0}$ in order to minimize the RMSPE. In our case, we chose to use all pre-treatment outcomes values without covariates in the main specification since it is the specification that allows us to apply the SCM on the longest time period and to have the largest number of units in the donor pool. While there is no specific recommendation about the variables that should be used in the SCM in Abadie et al. (2010), there is evidence supporting that different specifications used in synthetic control applications may lead to different results and different conclusions (Ferman et al., 2020). We conduct robustness checks in order to prove that different specifications would not affect our conclusion. Following Abadie et al. (2010), we also use three pre-treatment outcome values alongside covariates using two sets of data sets (IDPR and DHS data). Covariates from IDPR data were only available for 19 provinces and 17 years (1996-2012) and DHS data were available for 25 provinces and 26 years (1992-2017). However given that the inclusion of these covariates led to a large reduction of our panel due to missing data and to a larger RMSPE, we chose not to include covariates in the main results presented. We however present the results when including covariates in Appendix 4.

Composition of the donor pool and characeristics of Aceh are presented in Appendix 5.

In order to test whether the effects obtained are not due to chance, we use placebo tests as defined in Abadie et al. (2010). The placebo tests apply the synthetic control method to each unit of the donor pool. If this distribution in placebo effects denoted $\widehat{\alpha}_{1 t}^{P L}$ yields gaps as large as the estimated effect of the treated unit, then it is likely that the estimated effect observed in the treated unit was observed by chance. The p-value estimates the proportion of control units that have an estimated effect at least as large as that of the treated unit. The one-sided $\mathrm{p}$-values of post-treatment positive effects are given by $\mathrm{p}$-value $=\operatorname{Pr}\left(\widehat{\alpha}_{1 t}^{P L} \geq \widehat{\alpha}_{1 t}\right)$. However, it should be noted that placebo effects may be large in the presence of large RMSPE, which will cause p-values to be too conservative. In order to account for this, we adjust $\widehat{\alpha}_{1 t}$ for the quality of pre-treatment matches. To do this, we divide post-treatment effects by the corresponding pre-treatment match quality $\overleftarrow{s_{1}}$ to get a standardized effect measure and report the standardized p-value i.e. the proportion of placebo standardized effects that are at least as large as the main standardized effect for each post-treatment period. Untrimmed placebo tests graphs are 
presented in Appendix 6a and trimmed placebo tests graphs in Appendix 6b.

A consideration regarding the composition of the donor pool is its potential contamination. If some units of the donor pool are affected by the tsunami it will lead to an underestimation of its impact and to overestimation of the significance level (p-value). We exclude in all the estimates Aceh's neighbour province, Sumatra Utara, because this province was directly affected by the tsunami as shown in Figure 2 and was indirectly affected by population movement since most Acehnese who left Aceh were displaced to North Sumatra. In addition, one may want to note that at the time of the tsunami, Indonesia had 33 provinces but 7 provinces (Banten, Bangka Belitung, Riau islands, West Sulawesi, Gorontalo, North Maluku and West Papua) were created after 2000 i.e. 13 years after the beginning of our child cohort, so we replaced the identifiant of the newly province by the identifiant of the old province in order to maintain a similar donor unit over time. As such, our analysis is done as if provinces had not split. In addition, one province (North Kalimantan) had missing value. This explains why the donor pool contains 24 units.

\section{Results}

\subsection{Descriptive statistics}

Descriptive statistics are presented in Table 1. One can note that before the tsunami, child mortality indicators in Aceh were generally lower than in the donor pool. However, in 2005, under-5 mortality in Aceh is as much as twice larger than the one we observe in the donor pool (108 deaths per 1,000 live births in Aceh against 57 in the donor pool). Five years later, we can note that the level of under-5 mortality in Aceh has converged to the level we observe in the donor pool. Average in under-5 mortality rate however hides some important differences in trends between infant and children aged 1-4 years old. Table 1 shows that for children under-1, mortality in Aceh was still greater than the one in the donor pool in 2010 (53 deaths per 1,000 live births in Aceh against 38 in the donor pool) while mortality of children aged 1-4 was lower in Aceh than in the donor pool (0 death per 1,000 live births in Aceh against 14 in the donor pool).

Table 1 also shows a similar pattern observed for causes of mortality than for under- 5 mortality. Namely the fact that before the tsunami, Aceh had lower coverage of assisted delivery, facility- 
Figure 2: Number of tsunami related deaths per province
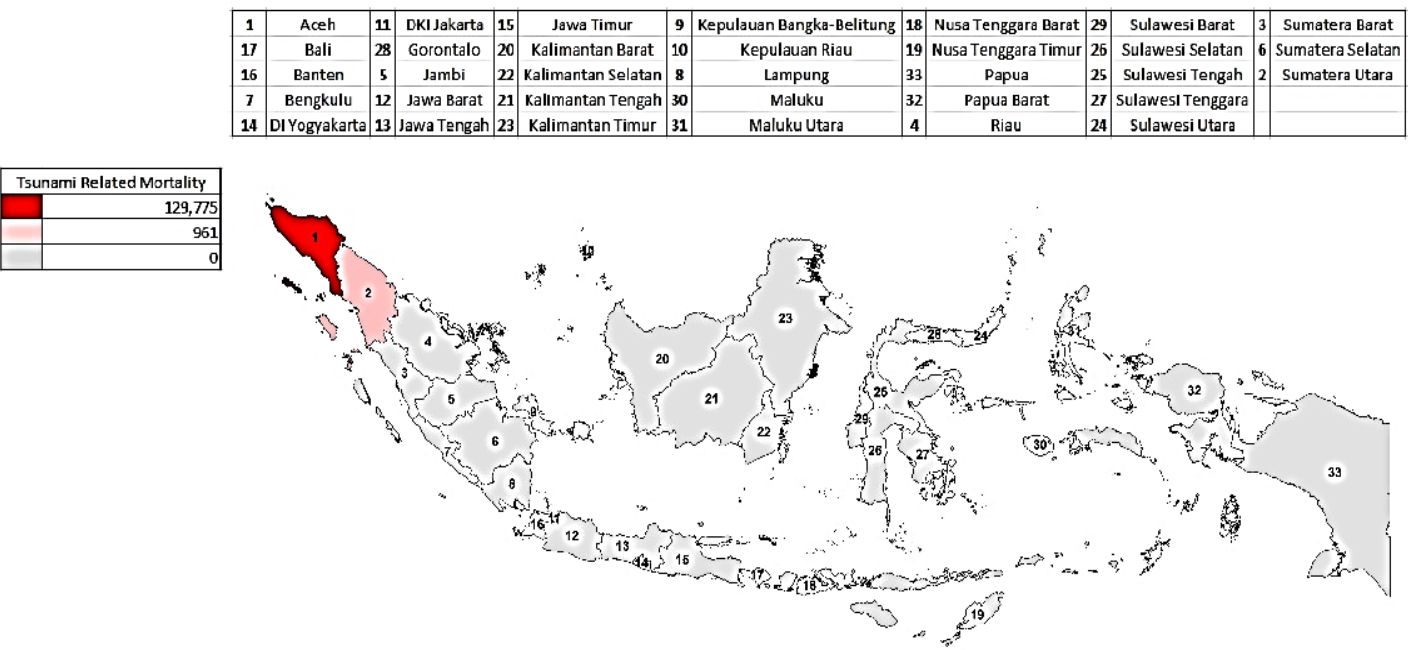

Source: Authors

based delivery, tetanus immunisation and access to safe water and sanitation than the donor pool. However, five years after the tsunami, all indicators, except the access to safe sanitation, have converged to the level we observe in the donor pool.

\subsection{Effect on Child mortality}

Results of the effect of the tsunami on child mortality are presented in Table 2. The results indicate that the tsunami only led to a significant increase in under-5 mortality in 2004 and in 2005, the year that followed the natural disaster. Results highlight that there is no longer term effect of the tsunami on child mortality.

Results presented in Figure 3 show two distinct peaks in under-5 mortality. The first one that led to an increase in mortality of 65 deaths per 1,000 live births was observed in 2005 and was explained by an increase in mortality among both under-1 and children aged 1-4. 
Table 1: Descriptive statistics

\begin{tabular}{|c|c|c|c|c|c|c|c|c|c|c|c|c|}
\hline & \multicolumn{2}{|l|}{1990} & \multicolumn{2}{|l|}{1995} & \multicolumn{2}{|l|}{2000} & \multicolumn{2}{|l|}{2005} & \multicolumn{2}{|l|}{2010} & \multicolumn{2}{|l|}{2015} \\
\hline Indicators & Aceh & $\begin{array}{l}\text { Donor } \\
\text { pool }\end{array}$ & Aceh & $\begin{array}{l}\text { Donor } \\
\text { pool }\end{array}$ & Aceh & $\begin{array}{l}\text { Donor } \\
\text { pool }\end{array}$ & Aceh & $\begin{array}{l}\text { Donor } \\
\text { pool }\end{array}$ & Aceh & $\begin{array}{l}\text { Donor } \\
\text { pool }\end{array}$ & Aceh & $\begin{array}{l}\text { Donor } \\
\text { pool }\end{array}$ \\
\hline $\begin{array}{lr}\text { Under-5 } & \text { mor- } \\
\text { tality } & \text { per } \\
1,000 & \text { live } \\
\text { births } & \end{array}$ & 65 & 109 & 56 & 73 & 57 & 69 & 108 & 57 & 50 & 47 & 41 & 38 \\
\hline $\begin{array}{lr}\text { Under-1 } & \text { mor- } \\
\text { tality } & \text { per } \\
1,000 & \text { live } \\
\text { births } & \end{array}$ & 48 & 73 & 34 & 56 & 43 & 49 & 72 & 40 & 48 & 35 & 28 & 27 \\
\hline $\begin{array}{ll}1-4 \text { year } & \text { old } \\
\text { mortality } & \text { per } \\
1,000 & \text { live } \\
\text { births } & \end{array}$ & 18 & 39 & 22 & 19 & 14 & 20 & 38 & 17 & 1 & 13 & 13 & 12 \\
\hline $\begin{array}{l}\text { Assisted deliv- } \\
\text { ery from qual- } \\
\text { ified provider } \\
(\%)\end{array}$ & - & - & 36 & 40 & - & - & 45 & 51 & 85 & 65 & 87 & 75 \\
\hline $\begin{array}{l}\text { Home-based } \\
\text { delivery }(\%)\end{array}$ & - & - & 90 & 78 & - & - & 78 & 58 & 40 & 44 & 19 & 26 \\
\hline $\begin{array}{l}\text { Antenatal } \\
\text { care from } \\
\text { qualified } \\
\text { provider }(\%)\end{array}$ & - & - & 89 & 0.91 & - & - & 88 & 94 & 99 & 95 & 97 & 96 \\
\hline $\begin{array}{l}\text { Prenatal } \\
\text { tetanus injec- } \\
\text { tion }(\%)\end{array}$ & - & - & 61 & 73 & - & - & 41 & 73 & 71 & 74 & 57 & 73 \\
\hline $\begin{array}{l}\text { Access to safe } \\
\text { water }(\%)\end{array}$ & - & - & 25 & 35 & 27 & 38 & 34 & 46 & 53 & 56 & 63 & 66 \\
\hline $\begin{array}{l}\text { Access to safe } \\
\text { sanitation (\%) }\end{array}$ & - & - & 46 & 50 & 51 & 55 & 48 & 60 & 59 & 64 & 67 & 73 \\
\hline
\end{tabular}

The second peak, which is of a lower magnitude than the first one, occurred in 2009 and is driven by an increase in mortality of children under-1. Infant mortality increased by 27 deaths per 1,000 live births in 2009 and by 31 deaths per 1,000 live births in 2010. These effects are large since this represents an increase in mortality close to $150 \%$ in comparison to its level in 2003 . Over the same period, the tsunami is found to have led to a statistically significant reduction in mortality of children aged between 1 and 4 years old. This reduction of 15 deaths per 1000 live births in 2011 represents a reduction of $65 \%$ in child mortality in comparison to its level in 2003. 
Table 2: Effect of the tsunami on child mortality indicators

\begin{tabular}{lcccccccccccccc}
\hline & 2004 & 2005 & 2006 & 2007 & 2008 & 2009 & 2010 & 2011 & 2012 & 2013 & 2014 & 2015 & 2016 & 2017 \\
\hline Under-5 mortality & $54.837^{* * *}$ & $64.969^{* * *}$ & 16.379 & 7.181 & -11.691 & $24.508^{* *}$ & 9.989 & -3.604 & 3.214 & -1.125 & -5.212 & 16.579 & -2.026 & -9.209 \\
Under-1 mortality & $36.249^{* * *}$ & $45.269^{* * *}$ & 22.318 & 15.885 & -12.243 & $27.170^{* * *}$ & $31.020^{*}$ & 16.612 & 7.595 & 5.093 & -5.403 & 12.800 & -0.560 & 11.712 \\
$1-4$ year old mortality & $12.351^{* *}$ & 12.189 & -0.436 & -6.763 & -6.362 & -11.408 & -16.141 & $-15.439^{* *}$ & $-14.367^{* *}$ & -4.314 & 0.605 & -0.564 & -2.397 & -16.176 \\
\hline \hline
\end{tabular}

Notes: The tables report the effects of the tsunami on child mortality indicators measured by the difference in level

in the treated unit and in the synthetic control. P-values are estimated by calculating the proportions of placebo

standardized effects that are at least as large as the main standardized effect for each post treatment period.

The donor pool includes 24 provinces.

Donor pool composition and RMSPE are presented in Appendix 5 and placebo test in Appendix 6. 
Figure 3: Synthetic control for estimation of the effect of the tsunami on child mortality Under-5 mortality (per 1,000 live births)

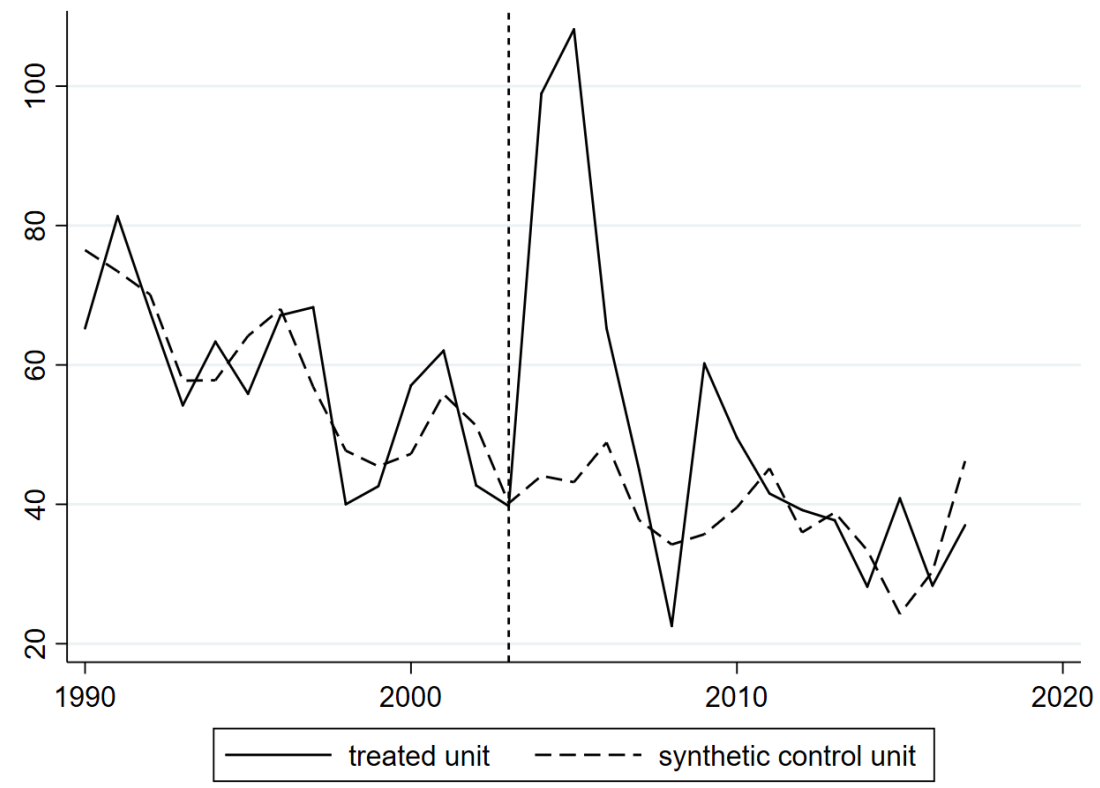

Under-1 mortality (per 1,000 live births) 1-4 years old mortality (per 1,000 live births)
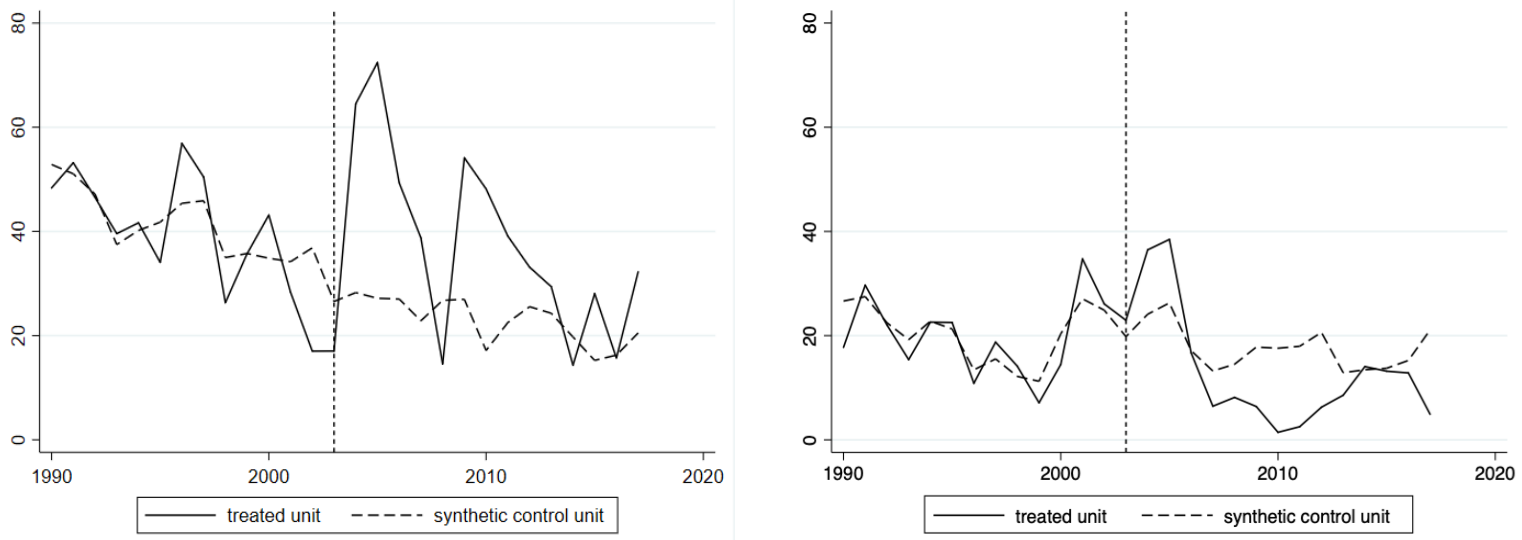

\subsection{Causes of child mortality}

Information collated from IHME on the main causes of death show that in 2005 the main causes of deaths among children under-5 were diarrhoeal diseases and lower respiratory diseases, accounting, respectively, for $19 \%$ and $17 \%$ of total deaths. In 2009, these two disease groups were also the main causes of deaths among children under-1, accounting, respectively, for $30 \%$ and $19 \%$ of total deaths. Lower respiratory diseases and diarrhoea are multifactorial diseases that are mainly the result of poor environmental conditions. Conversely, neonatal birth complications were the main cause of death among neonates. In order to investigate the effect of the 
tsunami on several causes of child mortality, we estimate its impact on the place and assistance during delivery at birth, antenatal care, prenatal tetanus injection, access to safe water and sanitation.

Results presented in Table 3 and Figure 4 show that overall the tsunami improved intermediary child health indicators in the medium term. For example, there is a significant increase in the proportion of assisted delivery in Aceh from 2007. In addition, there is an increase in antenatal care coverage in the medium term. Results also highlight a large increase in tetanus injection and a reduction in the proportion of mothers who deliver at home, although those effects are not statistically significant.

Conversely, results also highlight the detrimental effect of tsunami on vital systems. We show that the tsunami led to a statistically significant decrease in the access to safe water and sanitation the years that followed the tsunami.

While those results can provide some justifications for the observed short term increase in child mortality and the reduction of child mortality of older children in the medium term, the increase in mortality observed among under-1 in 2009 and 2010 remains unexplained. 
Table 3: Effect of the tsunami on the causes of deaths

\begin{tabular}{lcccccccccccccccccc}
\hline & 2004 & 2005 & 2006 & 2007 & 2008 & 2009 & 2010 & 2011 & 2012 & 2013 & 2014 & 2015 & 2016 & 2017 \\
\hline $\begin{array}{l}\text { Assisted delivery from } \\
\text { qualified provider (\%) }\end{array}$ & 0.043 & 0.021 & 0.007 & $0.151^{*}$ & 0.134 & $0.269^{* *}$ & $0.242^{* * *}$ & 0.156 & 0.167 & 0.123 & 0.138 & 0.126 & 0.063 & 0.155 \\
$\begin{array}{l}\text { Home delivery (\%) } \\
\text { Antenatal care from (\%) }\end{array}$ & 0.063 & 0.033 & -0.006 & -0.082 & -0.0871 & -0.072 & -0.149 & -0.059 & -0.143 & -0.098 & -0.086 & -0.151 & -0.233 & -0.211 \\
qualified provider(\%) & $-0.050^{*}$ & $-0.034^{* *}$ & $0.038^{*}$ & 0.024 & 0.043 & $0.071^{* * *}$ & $0.084^{* *}$ & $0.044^{*}$ & $0.084^{* *}$ & -0.005 & -0.005 & $0.045^{* *}$ & $0.041^{*}$ & $0.062^{*}$ \\
Prenatal tetanus injection (\%) & -0.050 & $-0.200^{*}$ & 0.013 & -0.070 & 0.132 & 0.153 & 0.153 & 0.167 & 0.108 & 0.103 & 0.019 & -0.013 & 0.064 & 0.092 \\
Access to safe water (\%) & 0.054 & -0.045 & -0.051 & -0.074 & -0.067 & -0.008 & 0.005 & 0.043 & 0.026 & 0.030 & 0.004 & 0.024 & 0.041 & 0.051 \\
Access to safe sanitation (\%) & 0.028 & $-0.085^{*}$ & $-0.110^{* * *}$ & -0.066 & -0.019 & -0.017 & -0.018 & -0.029 & -0.030 & -0.047 & -0.042 & -0.051 & -0.044 & -0.044 \\
\hline \hline
\end{tabular}

Notes: The tables report the effects of the tsunami on intermediary health indicators measured by the difference in level in

the treated unit and in the synthetic control. P-values are estimated by calculating the proportions of placebo standardized

effects that are at least as large as the main standardized effect for each post treatment period. 
Figure 4: Synthetic control for estimation of the effect of the tsunami on causes of child mortality

Assisted delivery at birth (\%)

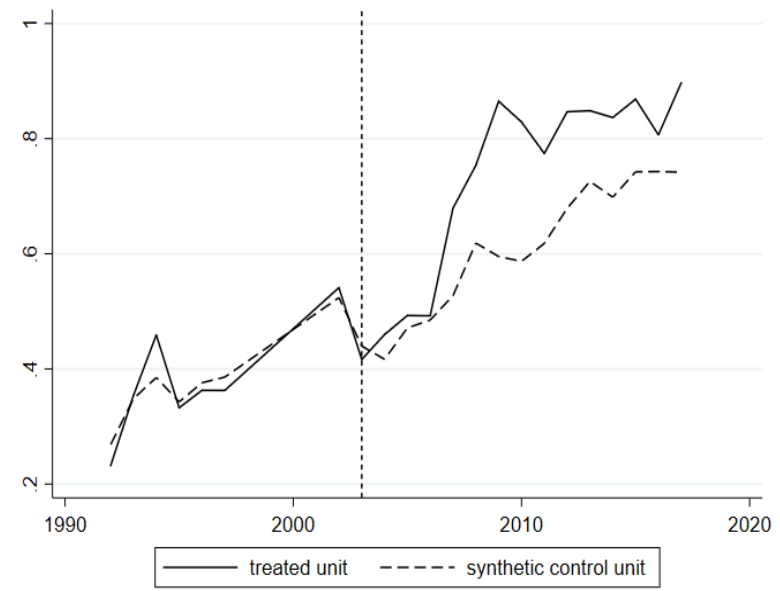

Home-based delivery (\%)

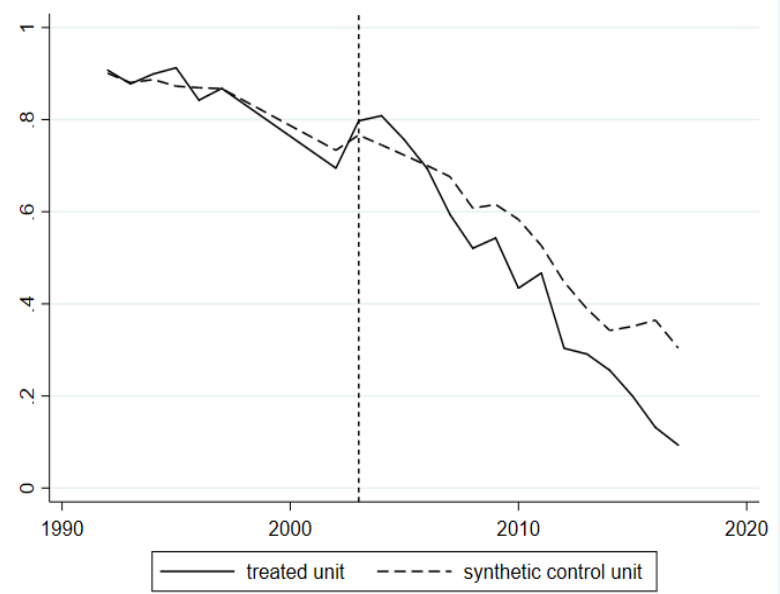

Access to sanitation (\%)

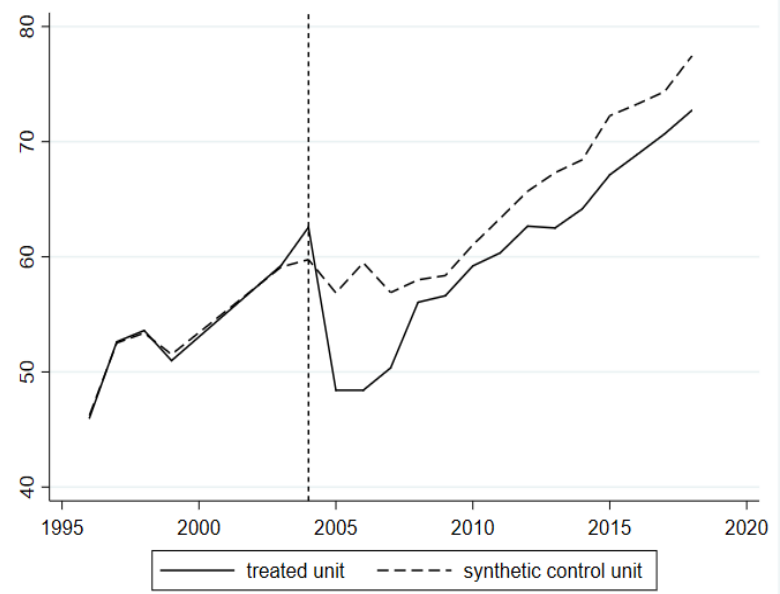

Received antenatal care (\%)

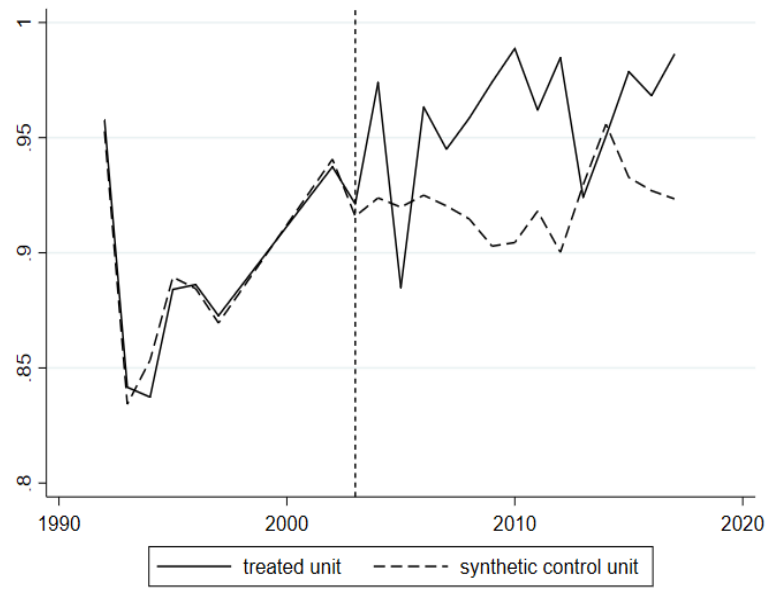

Tetanus immunisation before birth $(\%)$

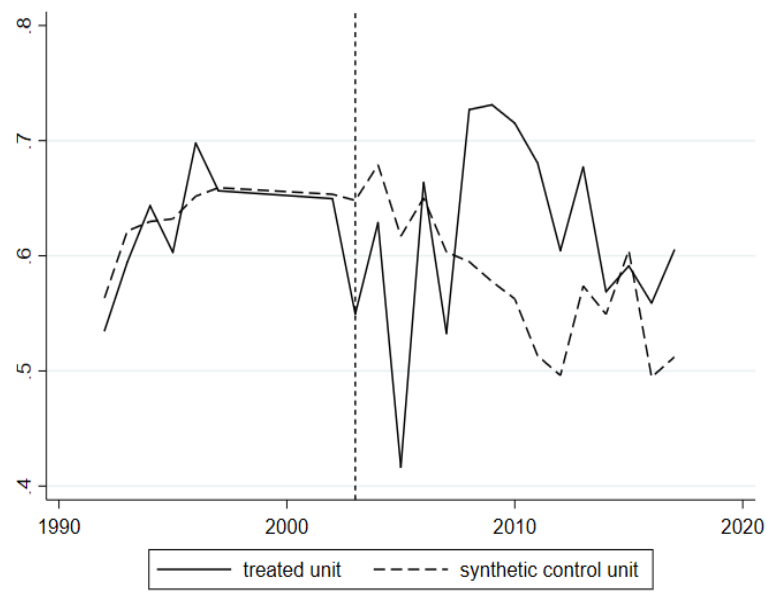

Access to safe water (\%)

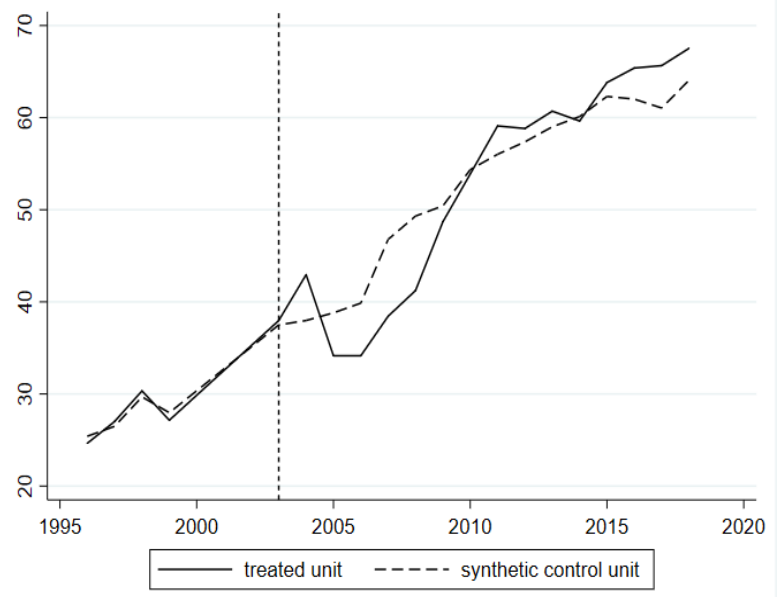




\subsection{Robustness checks}

We conduct several robustness checks. Firstly, we remove DI Yogyakarta from the donor pool given that this province was affected by an earthquake in $2006 .{ }^{7}$ By doing so we obtained close results but the quality of the synthetic control constructed was not as good given that this unit accounts for a large weight for several child mortality outcomes.

Gray et al. (2014) estimate that two-thirds of individuals who were living in severely affected area at the time of the disaster moved in the four months that followed the tsunami. Population displacement and returns may affect per capita health outcomes in the donor pool, hence it is important to ensure that effects on child mortality are not driven by migration patterns. We show in Table 4 that our results are not driven by changes in the population growth in the donor pool. More specifically, Figure 5 shows that the increase in population growth that occurred after the tsunami was not attributable to displaced populations coming back to Aceh, since there was an increase in population growth in the rest of the country. In addition, it is apparent that since 2007 population growth remains steady in both Aceh and its synthetic control.

The changes in government spending allocations may also potentially have been caused by the large influx in aid to central government and might have resulted in a reallocation of funds from other provinces towards Aceh. It is crucial to argue that an absence of effect is explained by Aceh's resilience rather than by a degradation in outcomes in the donor pool. We further identify in Table 4 and Figure 6 that although there was a noteworthy increase of per capita health and infrastructure function expenditure in Aceh, this did not occur at the expense of other Indonesian provinces. One may want to note that the increase in function expenditure did not come from aid relief because deconcentration funds, emergency funds, and reintegration of GAM funds were first channelled through Indonesian National Board for Disaster Management before being channelled through the Rehabilitation and Reconstruction Agency and do not seem to have been recorded in regional budgets.

The peace accord provided Aceh special autonomy status and new legislation on the governing of Aceh which provided additional revenue from central government general allocation funds and an increased share of own source revenue from a change in the revenue-sharing arrangements of oil and gas revenue (World Bank 2009, World Bank 2008, World Bank 2006). These additional

\footnotetext{
${ }^{7}$ Results are available from authors upon request.
} 
funds were meant to increase revenue and public spending in order to improve infrastructure, education, health and social programs. Additionally, Aceh saw an increase in their province tax revenue with the ending of violence, which previously had prohibited local government from collecting taxes and "increased economic activity generated by the influx of tsunami aid money into the local economy" (World Bank, 2006). Hence, this result suggests that the peace accord and subsequent changes to local government budgets led to an increase in government spending but did not take away central funding received by non-affected provinces.

In addition we provide a series of purely methodological robustness tests as suggested in Abadie, 2019. We first test the absence of anticipation effect by running our estimation while backdating the tsunami 5 years before its actual date (1999) and present results in Appendix 7a. The fact that the estimated effect of the tsunami appears after 2003 even when the event is artificially backdated in the data provides credibility to the synthetic control estimator of the tsunami and confirm absence of anticipation effect. In addition, we investigate how results are influenced by the choice of units in the donor pool. To do this, we conduct leave-one-out re-analysis taking from the sample one-at-a-time each of the Indonesian provinces that contribute to the synthetic control. Results of the leave-one-out re-analysis are presented in Appendix 7b and show that all leave-one-out estimates closely follow mortality indicators before the tsunami. The results are all consistent with results produced using the full donor pool. 
Table 4: Long-term effect of the tsunami on population growth, health and infrastructures spending

\begin{tabular}{|c|c|c|c|c|c|c|c|c|c|}
\hline & 2004 & 2005 & 2006 & 2007 & 2008 & 2009 & 2010 & 2011 & 2012 \\
\hline Population growth $(\%)$ & -0.037 & -0.034 & -0.012 & 0.000 & -0.001 & -0.001 & -0.001 & 0.006 & 0.004 \\
\hline Health Function expenditure per capita in $\mathrm{IDR}^{8}$ & $-5,365$ & $-7,287$ & $-9,318$ & 5,957 & 30,570 & $75,066^{*}$ & 88,958 & 105,950 & 104,419 \\
\hline Infrastructure Function expenditure per capita in IDR & 5,491 & $-15,004$ & $-2,053$ & 71,589 & $355,985^{* *}$ & $558,843^{* * *}$ & $386,903^{* * *}$ & $277,323^{*}$ & $305,956^{*}$ \\
\hline
\end{tabular}

Notes:The tables report the effects of the tsunami on indicators measured by the difference in level in the treated unit and in the synthetic control.

P-values are estimated by calculating the proportions of placebo standardized effects that are at least as large as the main standardized effect

for each post treatment period.

Figure 5: Pre- and post-tsunami trends in Aceh and its synthetic control for population growth

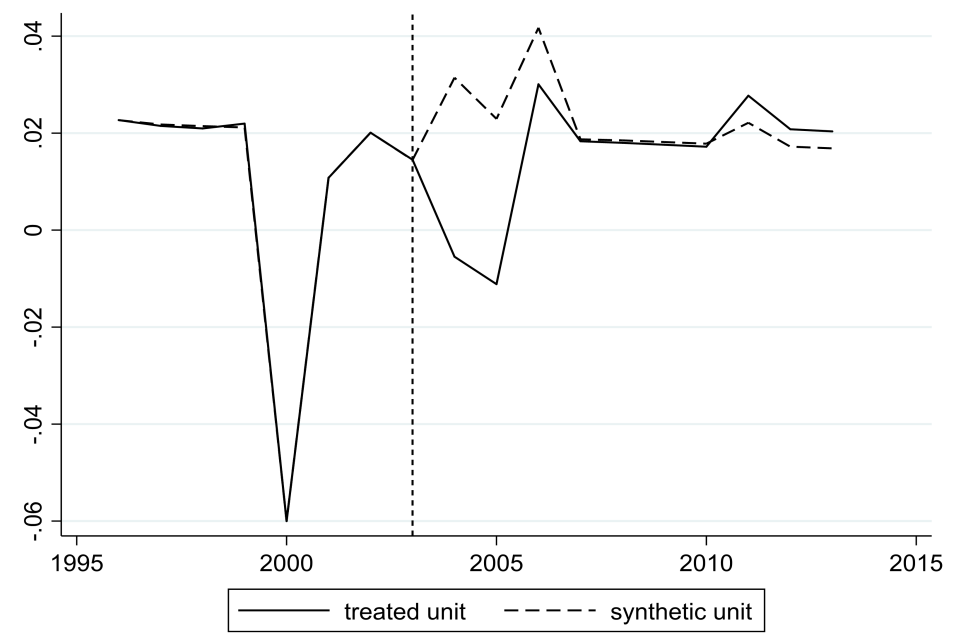


Figure 6: Pre- and post-tsunami trends in Aceh and its synthetic control for government expenditures per capita
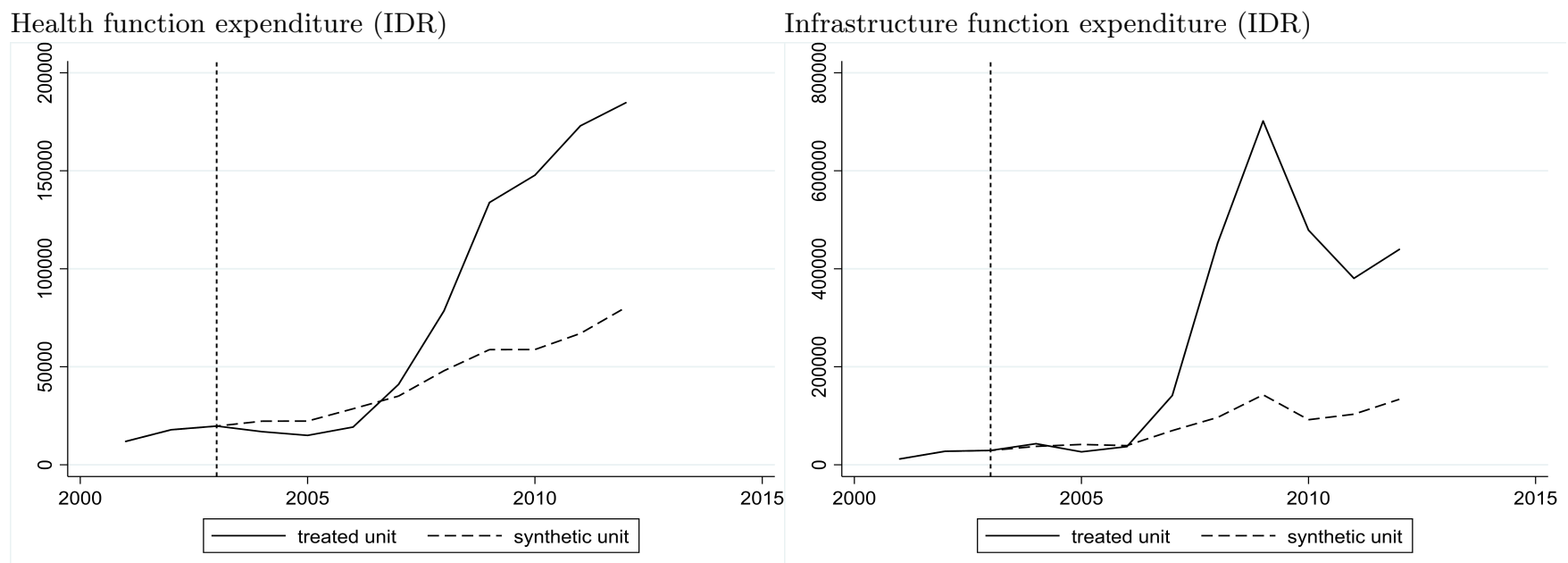


\section{Discussion}

Our paper makes use of the inability to forecast earthquakes and the existence of a large control group to reconstruct a valid counterfactual using the synthetic control method to estimate the effect of the 2004 tsunami on child mortality in Aceh province. We find that while there was no long term effect of the Indian Ocean tsunami on child mortality, it affected all children the year that followed the tsunami. Our results however highlight different patterns of mortality for different age groups. We find that the tsunami reduced mortality among children 1-4 years old in the medium term but increased mortality of younger children over the same period.

We showed that the increase in child mortality in 2005 is likely to be explained by a degradation in access to safe water and sanitation. In contrast, the investigation of the causes of mortality for children under-1 observed in 2009 and 2010 did not provide a clear explanation of the causes of death since there was no evidence of any deterioration in prenatal care and delivery. Selection into childbearing could also have longer term impact on child mortality. For instance it has been shown that the increase in fertility observed after the tsunami was driven by women who lost a child in the disaster and by women who did not have any children before the disaster (Nobles et al. 2014). While there is no available evidence regarding the characteristics of the second group, it has been shown that socio-economic factors did not explain much the probability of dying among women of childbearing age (Frankenberg et al., 2011). As a result, it is unlikely that the second peak in mortality observed among infants post-tsunami is due to selection into childbearing. While we cannot explicitly test for the reason of the delayed increased in mortality among the youngest children, the timing coincides with the end of aid relief. The results highlight that despite increase in assisted delivery, antenatal care and tetanus immunisation, there was an increase in infant mortality when international reconstruction projects ended. The World Bank 2009 reports highlights the effect on the end of aid on macroeconomic indicators by stating that "growth in Aceh's non-oil and gas declined sharply in 2008 as the reconstruction efforts winds down. As many reconstruction actors (NGOs, GOI) wind down or significantly scale down their operation in the province, sectors linked to the reconstruction effort that had led to growth in Aceh since 2005 registered low or negative growth"(World Bank, 2009a). Hence, the most likely explanation is that the end of aid projects led to an immediate decrease in the quality of care which may have negatively impacted infant health, especially neonatal health. This is a plausible explanation despite the observed increase in delivery outcomes and it has 
been found in other settings that an increase in assisted delivery at birth do not necessarily translate in improvement of child outcomes (Powell-Jackson, T. et al. 2015). Such finding can be explained by a quantity-quality trade-off.

The decrease in mortality among older children in the medium term coincides with improvement in environmental factors. However, this result could also be explained by an 'harvesting' effect, namely the fact that if the tsunami killed the most vulnerable children before the age of 1 , this selection in mortality may lead to a decrease in mortality later on among children of this age cohort and could explain the decrease in mortality observed later on among children aged between 1 an 4 years old.

The main limitation of our analysis relates to the potential contamination of the donor pool due to misplaced populations. For instance, if those with high morbidity were more likely to leave Aceh because of the tsunami, the effect of tsunami on morbidity would be underestimated. However, Gray et al. (2014) finds that a small proportion of total Acehnese families left their pre-tsunami home by April 2005 and that few were displaced from their community to Sumatra Utara, which we have excluded from the donor pool. Additionally, the analysis of population shows little difference in population between Aceh and the counterfactual over time and that there was no large increase in population in the counterfactual post-tsunami, which would have signalled a migration effect away from Aceh to donor pool provinces.

There is also little concern of aid funds contaminating the donor pool since many international relief agencies directly provided services in Aceh instead of funnelling aid through the local or national government. In fact, the Aceh government created a non-political body which was responsible for coordinating local reconstruction efforts with the help the Multi-Donor Fund to channel aid funds. This effort was revered as highly successful at retaining aid commitments and ensuring their effective local use (Masyrafah and McKeon, 2008). Furthermore, the analysis shows that the counterfactual, consisting of the donor provinces, did not have an abnormally large increase in government expenditure after the tsunami. This suggests that aid did not create an exogenous increase in government health budget across donor provinces.

The final hypothesized limitation of our findings is the possibility that the results are overestimated given the potential of a shift in central government funding due to the 2005 peace 
accord. More specifically, the peace accord gave Aceh province a larger percentage of its oil and gas revenues, previously kept by the central government (World Bank, 2009b, Shah and Cardozo, 2014). This dramatically increased Aceh's local government budget, which was used for investment in local services (Shah and Cardozo, 2014). If the central government previously dispersed these oil revenue funds to other provinces, and then post-peace accord may have taken these funds away from the donor provinces, so that the shift in donor province budgets would degrade the donor pool health function expenditure and possibly influence health outcomes. If a change in donor province government budgets is not exogenous, but targeted and reallocated from donor provinces to Aceh province, then the tsunami treatment effects would be overestimated.

Another limitation is the fact that information on child mortality is reported by the mother in DHS. It is likely that mothers who had children who died during the tsunami also died and this could explain why our results should not be used to estimate the number of children who died during the tsunami in 2004 .

\section{Conclusion}

Each year there are over 300 natural disasters globally, resulting in millions of victims and economic losses near USD $\$ 100$ billion. With the increase incidence in climate variation and intensity of natural disasters, understanding the impact of these shocks on population health is vital to improve resilience of health systems. We investigate the effect of one the deadliest natural disasters in history and find that the disaster increased child mortality immediately after the tsunami. However, we show mixed evidence of the combined effect of such disaster on child mortality in the medium term since children were affected differently depending on their age. Our systematic literature review identified several transmission channels in the Indonesian context through which the tsunami may have impacted child health. While we were not able to disentangle these impacts empirically, the review confirmed that the response to this disaster was complex and that the coordinated international aid played an important role in the reconstruction process in Aceh. 


\subsection{Appendix 1: Literature review method}

The literature search focused on two elements, searches that would return articles that focused on direct health outcomes post-tsunami and articles that would illuminate hypothesized pathways to longer-term health effects. Below are the search strings and results of each of the two searches.

Table 5: Search strategy: short term effect

\begin{tabular}{|c|c|c|c|c|}
\hline \multicolumn{5}{|l|}{$\begin{array}{l}\text { Health outcomes } \\
\text { search string }\end{array}$} \\
\hline \multicolumn{2}{|l|}{ Health AND } & \multicolumn{2}{|l|}{ Tsunami AND } & Indonesia \\
\hline \multicolumn{2}{|c|}{$\begin{array}{l}\text { health OR sanitation OR } \\
\text { water quality OR assisted } \\
\text { deliver* OR birth OR } \\
\text { morbidity OR mortality } \\
\text { OR health expenditure OR } \\
\text { health ADJ2 spending OR } \\
\text { mental health OR medicine } \\
\text { OR health ADJ2 outcome* } \\
\text { OR access to care OR } \\
\text { health ADJ2 impact* OR } \\
\text { health seeking behaviour } \\
\text { OR health seeking be- } \\
\text { havior OR hospital* OR } \\
\text { nurse* OR out of pocket } \\
\text { payment }\end{array}$} & \multicolumn{2}{|c|}{$\begin{array}{l}\text { tsunami OR earth- } \\
\text { quake OR natural } \\
\text { disaster* AND } 2004\end{array}$} & $\begin{array}{l}\text { Indonesia* OR Aceh OR } \\
\text { Sumatra OR Sumatera } \\
\text { Utara OR Nanggroe OR } \\
\text { Banda Aceh }\end{array}$ \\
\hline \multicolumn{5}{|c|}{$\begin{array}{l}\text { Health Outcomes } \\
\text { Database Search } \\
\text { Results }\end{array}$} \\
\hline Database & Date & & No. & Results \\
\hline Medline/PubMed & June 2 & & 26 & \\
\hline EMBASE & June 2 & & 31 & \\
\hline Global Health & June 2 & & 12 & \\
\hline Scopus & June 2 & & 5 & \\
\hline $\begin{array}{l}\text { Web of Science: } \\
\text { Core Collection }\end{array}$ & June 2 & & 151 & \\
\hline IBSS & June 2 & & 22 & \\
\hline $\begin{array}{l}\text { Social Policy and } \\
\text { Practice }\end{array}$ & April 2 & & 0 & \\
\hline
\end{tabular}


Table 6: Search strategy: medium and long term effect

\begin{tabular}{|c|c|c|c|c|}
\hline \multicolumn{5}{|l|}{$\begin{array}{lr}\text { Pathways } & \text { to } \\
\text { long-term } & \text { health } \\
\text { outcomes } & \text { search } \\
\text { string } & \end{array}$} \\
\hline \multicolumn{2}{|c|}{ Factors of Interest AND } & \multicolumn{2}{|c|}{ Tsunami AND } & Indonesia \\
\hline \multicolumn{2}{|c|}{$\begin{array}{l}\text { religion OR Islam OR civil- } \\
\text { war OR conflict OR aid } \\
\text { OR donation OR gov- } \\
\text { ern* OR economy OR eco- } \\
\text { nomics OR society OR wel- } \\
\text { fare OR development OR } \\
\text { growth OR innovation OR } \\
\text { re-construction OR invest- } \\
\text { ment OR relief OR cor- } \\
\text { ruption OR trauma OR } \\
\text { poverty }\end{array}$} & \multicolumn{2}{|c|}{$\begin{array}{l}\text { tsunami OR earth- } \\
\text { quake OR natural } \\
\text { disaster* AND } 2004\end{array}$} & $\begin{array}{l}\text { Indonesia* OR Aceh OR } \\
\text { Sumatra OR Sumatera } \\
\text { Utara OR Nanggroe OR } \\
\text { Banda Aceh }\end{array}$ \\
\hline \multicolumn{5}{|c|}{$\begin{array}{l}\text { Pathways to } \\
\text { Long-Term } \\
\text { Health Outcomes } \\
\text { Database Search } \\
\text { Results }\end{array}$} \\
\hline Database & \multicolumn{2}{|l|}{ Date } & \multicolumn{2}{|c|}{ No. Results } \\
\hline Medline/PubMed & \multicolumn{2}{|c|}{ June 2017} & \multicolumn{2}{|c|}{73} \\
\hline EMBASE & \multicolumn{2}{|c|}{ June 2017} & \multicolumn{2}{|l|}{82} \\
\hline Global Health & \multicolumn{2}{|c|}{ June 2017} & \multicolumn{2}{|l|}{37} \\
\hline Scopus & \multicolumn{2}{|c|}{ June 2017} & \multicolumn{2}{|c|}{18} \\
\hline $\begin{array}{l}\text { Web of Science: } \\
\text { Core Collection }\end{array}$ & \multicolumn{2}{|c|}{ June 2017} & \multicolumn{2}{|c|}{531} \\
\hline IBSS & \multicolumn{2}{|c|}{ June 2017} & \multicolumn{2}{|c|}{170} \\
\hline $\begin{array}{l}\text { Social Policy and } \\
\text { Practice }\end{array}$ & \multicolumn{2}{|c|}{ April 2017} & \multicolumn{2}{|c|}{4} \\
\hline
\end{tabular}

Once the articles were collected from the two searches they were subjected to title and abstract review from which it was decided that if they met inclusion criteria they would be kept in the review. Once articles were selected for inclusion only those that were able to be accessed in full text were used for the review. 
Figure 7: Study flow diagram

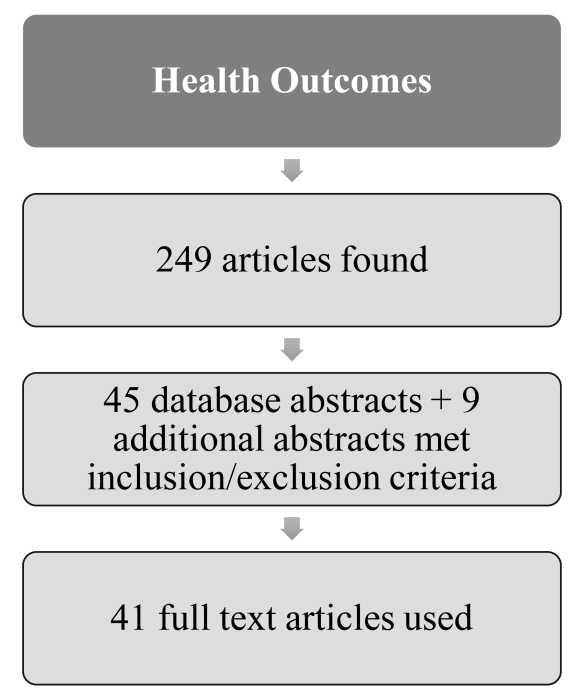

\section{Pathways to Long-Term Health \\ Outcomes}

$\sqrt{2}$

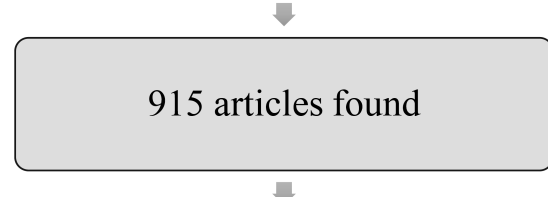

141 database abstracts +34 additional abstracts met inclusion/exclusion criteria

$\checkmark$

37 full text articles used 


\subsection{Appendix 2: Literature review results}

\subsubsection{Negative effect}

\begin{tabular}{|c|c|c|c|c|c|c|}
\hline $\begin{array}{l}\text { Author/ Add insti- } \\
\text { tution }\end{array}$ & Study Type & Method & Population/ Study Size & Modifying Factor & $\begin{array}{l}\text { Outcome of In- } \\
\text { terest }\end{array}$ & Correlation or causal effect \\
\hline $\begin{array}{l}\text { Guha-Sapir et al. } \\
(2007)\end{array}$ & $\begin{array}{l}\text { Peer reviewed analysis of } \\
\text { patterns of disease after } \\
\text { tsunami }\end{array}$ & $\begin{array}{l}\text { Cross-sectional record study } \\
\text { of Red-Cross field hospital }\end{array}$ & $\begin{array}{l}\text { 1,188 Aceh resident records } \\
\text { January } 15-31\end{array}$ & $\begin{array}{l}\text { Limited care seek- } \\
\text { ing behaviour }\end{array}$ & Morbidity & $\begin{array}{l}\text { Odds of chronic vs acute disease increased by } 16.4 \% \text { per } \\
\text { day }\left(95 \% \mathrm{CI} \text { 7.8-25.6) until the } 23^{r d} \text { and decreased } 13.1 \%\right. \\
\text { after }(95 \% \mathrm{CI} \text { 6.6-19.1) signalling a delay in care for acute } \\
\text { conditions that have negative implications for long-term } \\
\text { health }\end{array}$ \\
\hline 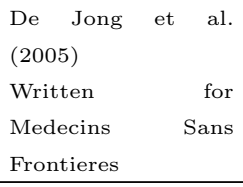 & $\begin{array}{l}\text { Field report in peer re- } \\
\text { viewed journal }\end{array}$ & $\begin{array}{l}\text { Observations from field work- } \\
\text { ers }\end{array}$ & $\begin{array}{l}\text { Medical, logistical, wa- } \\
\text { ter/sanitation and mental } \\
\text { health teams using rapid } \\
\text { assessments }\end{array}$ & $\begin{array}{l}\text { Cultural views of } \\
\text { mental health }\end{array}$ & Morbidity & Negative association \\
\hline Doocy et al. (2009) & $\begin{array}{l}\text { Peer reviewed demo- } \\
\text { graphic survey collection } \\
\text { and analysis }\end{array}$ & $\begin{array}{l}\text { Surveys of mortality and in- } \\
\text { jury impact }\end{array}$ & $\begin{array}{l}\text { Three surveys across dis- } \\
\text { tricts in Aceh with } 7310 \\
\text { households }\end{array}$ & $\begin{array}{l}\text { Location, demo- } \\
\text { graphics }\end{array}$ & $\begin{array}{l}\text { Injury, morbid- } \\
\text { ity, mortality, } \\
\text { care seeking } \\
\text { behaviour }\end{array}$ & $\begin{array}{l}\text { Odds of mortality } 1.41 \% \text { ( } 95 \% \text { CI } 1.27-1.58 \text { ) times greater } \\
\text { for women, Odds of injury } 0.81(95 \% \text { CI } 0.61-0.96 \text { ) for } \\
\text { women. Highest mortality } 23.6 \% \text { ( } 95 \% \text { CI } 17.8-29.4 \text { in } \\
\text { west coast versus } 5.3 \% \text { ( } 95 \% \text { CI } 1.3-8.0 \text { east coast. }\end{array}$ \\
\hline $\begin{array}{l}\text { Jeremijenko et al. } \\
(2007)\end{array}$ & $\begin{array}{l}\text { Peer reviewed tetanus } \\
\text { outbreak summary }\end{array}$ & $\begin{array}{l}\text { Standard reporting and ac- } \\
\text { tive case finding report }\end{array}$ & $\begin{array}{l}\text { Clinical review in } 8 \text { hospi- } \\
\text { tals in Aceh }\end{array}$ & $\begin{array}{l}\text { Limited immu- } \\
\text { nization, illness, } \\
\text { poor access to } \\
\text { care }\end{array}$ & $\begin{array}{l}\text { Morbidity, } \\
\text { mortality, child } \\
\text { health }\end{array}$ & $\begin{array}{l}\text { Mortality rate } 19 \% \text {, projection that limited care was a } \\
\text { result of inability to reach a hospital leading to negative } \\
\text { morbidity/mortality outcomes }\end{array}$ \\
\hline $\begin{array}{l}\text { Pascapurnama et al. } \\
(2016)\end{array}$ & $\begin{array}{l}\text { Peer reviewed system- } \\
\text { atic literature review of } \\
\text { tetanus outbreaks }\end{array}$ & $\begin{array}{l}\text { Systematic literature review } \\
\text { of PubMed, WHO website } \\
\text { and books }\end{array}$ & 16 publications reviewed & $\begin{array}{l}\text { Poor access to } \\
\text { care and low } \\
\text { vaccination }\end{array}$ & $\begin{array}{l}\text { Morbidity, mor- } \\
\text { tality }\end{array}$ & $\begin{array}{l}\text { Positive association between limited access to health care } \\
\text { facilities and case fatality ration (18.9\%) }\end{array}$ \\
\hline $\begin{array}{l}\text { Redwood-Campbell } \\
\text { and Riddez (2012) }\end{array}$ & $\begin{array}{l}\text { Peer reviewed descrip- } \\
\text { tion of post-disaster ill- } \\
\text { ness and casualty }\end{array}$ & $\begin{array}{l}\text { Prospective reporting of de- } \\
\text { pression and Post-traumatic } \\
\text { Stress Disorder screening in } \\
\text { Red Cross field hospital }\end{array}$ & $\begin{array}{l}5 \text { day review of } 271 \text { pa- } \\
\text { tients registered in ICRC } \\
\text { hospital in Banda Aceh }\end{array}$ & $\begin{array}{l}\text { Limited access } \\
\text { to mental health } \\
\text { care }\end{array}$ & Morbidity & $\begin{array}{l}24 \% \text { of patients had at least } 4 / 7 \text { depression/PTSD symp- } \\
\text { toms yet } 1.4 \% \text { received mental health diagnosis. Study } \\
\text { authors report that there is a need for better assessment } \\
\text { and mental health response }\end{array}$ \\
\hline Gupta et al. (2007) & $\begin{array}{l}\text { Peer reviewed study of } \\
\text { factors associated with } \\
\text { water contamination }\end{array}$ & $\begin{array}{l}\text { Water quality sampling and } \\
\text { survey to households about } \\
\text { water storage }\end{array}$ & $\begin{array}{l}\text { Survey of } 1,127 \text { households } \\
\text { in Aceh Besar, Simeulue } \\
\text { and Nias }\end{array}$ & $\begin{array}{l}\text { Poor water qual- } \\
\text { ity and sanitation }\end{array}$ & Morbidity & $\begin{array}{l}\text { Found improved water sources and handling was associ- } \\
\text { ated with decreased risk of contamination. Author notes } \\
\text { relationship between water quality and morbidity but } \\
\text { does not test morbidity }\end{array}$ \\
\hline Patunru (2015) & $\begin{array}{l}\text { Peer reviewed analysis } \\
\text { of Indonesian progress } \\
\text { towards meeting millen- } \\
\text { nium development goals }\end{array}$ & $\begin{array}{l}\text { Multivariate logistic regres- } \\
\text { sion analysis of WHO and } \\
\text { UNICEF data }\end{array}$ & $\mathrm{N} / \mathrm{A}$ & $\begin{array}{l}\text { Poor water qual- } \\
\text { ity and lack of im- } \\
\text { proved sanitation } \\
\text { infrastructure }\end{array}$ & Morbidity & $\begin{array}{l}\text { Individuals without access to improved sanitation infras- } \\
\text { tructure have } 1.27 \text { [CI } 1.25 ; 1.29 \text { ] times the risk ( } 27 \text { per- } \\
\text { cent higher chance) of having diarrhoea }\end{array}$ \\
\hline
\end{tabular}




\begin{tabular}{|c|c|c|c|c|c|c|}
\hline $\begin{array}{l}\text { Athukorala and Re- } \\
\text { sosudarmo (2005) }\end{array}$ & $\begin{array}{l}\text { Peer reviewed economic } \\
\text { impact and disaster } \\
\text { management report }\end{array}$ & $\begin{array}{l}\text { Review of past disasters and } \\
\text { response, Impact assessment } \\
\text { of } 2004 \text { tsunami }\end{array}$ & & $\begin{array}{l}\text { Socio-political } \\
\text { instability, con- } \\
\text { strained informa- } \\
\text { tion sharing, poor } \\
\text { infrastructure }\end{array}$ & $\begin{array}{l}\text { Limited disas- } \\
\text { ter response, } \\
\text { morbidity }\end{array}$ & Suggested association \\
\hline Webb (2005) & $\begin{array}{l}\text { Peer reviewed account of } \\
\text { food and nutrition as- } \\
\text { sessment teams experi- } \\
\text { ence in Aceh }\end{array}$ & $\begin{array}{l}\text { Emergency needs assessment } \\
\text { conducted by UN agencies } \\
\text { with the Indonesian Govern- } \\
\text { ment }\end{array}$ & $\begin{array}{l}\text { Non-statistically represen- } \\
\text { tative of population, } 30 \text { lo- } \\
\text { cations reviewed }\end{array}$ & $\begin{array}{l}\text { Poor nutrition ac- } \\
\text { cess }\end{array}$ & $\begin{array}{l}\text { Morbidity, mor- } \\
\text { tality }\end{array}$ & $\begin{array}{l}\text { Authors suggest that "there was a danger of major loss } \\
\text { of life in the absence of [food] interventions" }\end{array}$ \\
\hline $\begin{array}{l}\text { Agustini et al. } \\
(2011)\end{array}$ & $\begin{array}{l}\text { Peer reviewed analysis } \\
\text { of association between } \\
\text { trauma exposure and } \\
\text { persistence of PTSD } \\
\text { symptoms }\end{array}$ & $\begin{array}{l}\text { Child Post- } \\
\text { Traumatic Stress Reaction } \\
\text { Index survey \& Traumatic } \\
\text { Exposure Severity Scale }\end{array}$ & $\begin{array}{l}48211-19 \text { year old tsunami } \\
\text { survivors in Aceh }\end{array}$ & $\begin{array}{lr}\text { Trauma } & \text { expo- } \\
\text { sure, } & \text { mental } \\
\text { health, } & \text { parental } \\
\text { mortality } & \end{array}$ & Morbidity & $\begin{array}{l}\text { Positive association between trauma exposure and per- } \\
\text { sistence of PTSD symptoms } 4.5 \text { years later }\end{array}$ \\
\hline $\begin{array}{l}\text { Frankenberg et al. } \\
(2008)\end{array}$ & $\begin{array}{l}\text { Peer reviewed analysis } \\
\text { of correlation between } \\
\text { PTSR and tsunami ex- } \\
\text { posure intensity }\end{array}$ & $\begin{array}{l}\text { Survey analysis of Post- } \\
\text { Traumatic Stress Reactivity } \\
\text { interviews before and after } \\
\text { tsunami }\end{array}$ & $\begin{array}{l}20,500 \text { adults from Aceh } \\
\text { and North Sumatra } 5 \text { to } 17 \\
\text { months after tsunami }\end{array}$ & $\begin{array}{l}\text { Tsunami expo- } \\
\text { sure }\end{array}$ & $\begin{array}{l}\text { Morbidity } \\
\text { (mental health) }\end{array}$ & $\begin{array}{l}\text { As distance from coast increased, PTSR scores decreased } \\
\text { indicating better mental health. Distance from coast } \\
\text { (KM) -.02 in PTSR score }(95 \% \text { CI -.03-.01) }\end{array}$ \\
\hline $\begin{array}{l}\text { Frankenberg et al. } \\
\text { (2013a) }\end{array}$ & $\begin{array}{l}\text { Unpublished manuscript } \\
\text { investigating the effect of } \\
\text { tsunami on child height }\end{array}$ & $\begin{array}{l}\text { Multivariate linear regression } \\
\text { comparing height of cohorts } \\
\text { in utero at tsunami to an } \\
\text { older cohort }\end{array}$ & 4,170 children in Aceh & $\begin{array}{l}\text { Tsunami expo- } \\
\text { sure }\end{array}$ & $\begin{array}{l}\text { Morbidity } \\
\text { (child height) }\end{array}$ & $\begin{array}{l}\text { Children exposed to tsunami in utero have a lower height } \\
\text { of one third than children born 3-4 years earlier. }\end{array}$ \\
\hline $\begin{array}{l}\text { Frankenberg et al. } \\
(2012)\end{array}$ & $\begin{array}{l}\text { Peer reviewed analysis of } \\
\text { traumatic stress }\end{array}$ & $\begin{array}{l}\text { Multilevel linear regression } \\
\text { model with satellite mapping } \\
\text { and informant interviews }\end{array}$ & $\begin{array}{l}27,624 \text { STAR respondents } \\
\text { from Aceh and North } \\
\text { Sumatra. } \\
16,709 \text { of } \text { Additional } \\
\text { interviewed. }\end{array}$ & $\begin{array}{l}\text { Community de- } \\
\text { struction }\end{array}$ & $\begin{array}{l}\text { Morbidity } \\
\text { (post-traumatic } \\
\text { stress) }\end{array}$ & $\begin{array}{l}\text { 1-point increase in exposure to tsunami is associated } \\
\text { with } .81 \text { increase in PTSR score. Community destruc- } \\
\text { tion worsens stress reaction. }\end{array}$ \\
\hline (Frankenberg, 2007) & $\begin{array}{l}\text { Peer reviewed analysis } \\
\text { of the condition of pub- } \\
\text { lic services after the } \\
\text { tsunami }\end{array}$ & Descriptive statistics & $\begin{array}{l}\text { Community and facility } \\
\text { characteristics located in } \\
\text { the } 591 \text { villages targeted } \\
\text { by STAR }\end{array}$ & $\begin{array}{l}\text { Tsunami expo- } \\
\text { sure }\end{array}$ & $\begin{array}{l}\text { Morbidity } \\
\text { (health ser- } \\
\text { vices) }\end{array}$ & High destruction of health services after the tsunami. \\
\hline $\begin{array}{l}\text { Irmansyah et al. } \\
(2010)\end{array}$ & $\begin{array}{l}\text { Peer reviewed analysis } \\
\text { of determinants of psy- } \\
\text { chological morbidity af- } \\
\text { ter tsunami }\end{array}$ & $\begin{array}{l}\text { Multiple linear regression } \\
\text { analysis of self-reported } \\
\text { questionnaire of disaster } \\
\text { exposure and measure of } \\
\text { resilience }\end{array}$ & $\begin{array}{l}783 \text { people in Aceh } \\
\text { both displaced and non- } \\
\text { displaced. }\end{array}$ & $\begin{array}{l}\text { Displacement, } \\
\text { tsunami exposure }\end{array}$ & $\begin{array}{l}\text { Morbidity } \\
\text { (mental health) }\end{array}$ & $\begin{array}{l}\text { Each increase in impact level had } .416 \text { increase in pre- } \\
\text { dicted SRQ- } 20 \text { score of post-traumatic stress symptoms } \\
\text { IDP status had } .324 \text { increase in predicted score. }\end{array}$ \\
\hline Lee et al. (2015) & $\begin{array}{l}\text { Peer reviewed analysis } \\
\text { of causes of impairment } \\
\text { in tsunami-exposed chil- } \\
\text { dren }\end{array}$ & $\begin{array}{l}\text { Multivariate linear modelling } \\
\text { of predictors of impairment } \\
\text { using Brief Impairment Scale }\end{array}$ & $\begin{array}{l}138 \text { displaced and non- } \\
\text { displaced Acehnese chil- } \\
\text { dren }\end{array}$ & $\begin{array}{l}\text { Displacement dis- } \\
\text { tance }\end{array}$ & $\begin{array}{l}\text { Morbidity } \\
\text { (mental health) }\end{array}$ & $\begin{array}{l}\text { Displacement distance predicted impairment, one KM of } \\
\text { displacement increased interpersonal subscalse score by } \\
.213 \text { points }(.0335-.393, \mathrm{p}=.026) \text { and impairment by } .149 \\
\text { points }(.015-0.282, \mathrm{p}=.033)\end{array}$ \\
\hline
\end{tabular}




\begin{tabular}{|c|c|c|c|c|c|c|}
\hline $\begin{array}{l}\text { Guha-Sapir and van } \\
\text { Panhuis (2009) }\end{array}$ & $\begin{array}{l}\text { Peer reviewed analysis } \\
\text { of infection disease and } \\
\text { injury consequences of } \\
\text { tsunami }\end{array}$ & $\begin{array}{l}\text { Epidemiological profile of dis- } \\
\text { ease survey before and after } \\
\text { tsunami using field hospital } \\
\text { records and historic records } \\
\end{array}$ & & Illness & Morbidity & $\begin{array}{l}\text { Negative association observed between increased in- } \\
\text { stance of wounds mixed with lack of vaccination in Aceh } \\
\text { against tetanus and tetanus infections leading to in- } \\
\text { creased morbidity }\end{array}$ \\
\hline Schwab et al. (2016) & $\begin{array}{l}\text { Peer reviewed as- } \\
\text { sessment of preterm } \\
\text { deliveries associated } \\
\text { with infection } \\
\end{array}$ & Wet mount microscopy & $\begin{array}{l}159 \text { women screened from } \\
\text { Banda Aceh in February- } \\
\text { June of } 2005 \text { post-disaster }\end{array}$ & $\begin{array}{l}\text { Stress, demo- } \\
\text { graphics }\end{array}$ & Morbidity & $\begin{array}{l}\text { Study found higher than normal pre-term delivery in this } \\
\text { population which they suspect high levels of stress was } \\
\text { a risk factor in negative birth outcome }\end{array}$ \\
\hline $\begin{array}{l}\text { Urlainis et al. } \\
(2014)\end{array}$ & $\begin{array}{l}\text { Peer reviewed litera- } \\
\text { ture review of extreme } \\
\text { weather events }\end{array}$ & $\begin{array}{l}\text { Literature Review of extreme } \\
\text { events impact on critical in- } \\
\text { frastructure and review of } \\
\text { strategies and their imple- } \\
\text { mentation }\end{array}$ & $\begin{array}{l}8 \text { events, including the } \\
2004 \text { Indian Ocean tsunami }\end{array}$ & $\begin{array}{l}\text { Lack of pre- } \\
\text { warning system }\end{array}$ & Morbidity & $\begin{array}{l}\text { Author states that appropriate disaster alert systems and } \\
\text { preparation could have reduced loss of life and that crit- } \\
\text { ical infrastructure was destroyed because of poor design } \\
\text { and consideration of tsunami possibility }\end{array}$ \\
\hline $\begin{array}{l}\text { Hayat and Ama- } \\
\text { ratunga (2014) }\end{array}$ & $\begin{array}{l}\text { Peer reviewed analysis } \\
\text { of political factors in- } \\
\text { fluencing governance and } \\
\text { road development post- } \\
\text { disaster }\end{array}$ & $\begin{array}{l}\text { Semi-structured interviews } \\
\text { with infrastructure stake- } \\
\text { holders }\end{array}$ & $\begin{array}{l}\text { Road infrastructure stake- } \\
\text { holders }(\mathrm{n}=28) \text { in } 4 \text { dis- } \\
\text { tricts in Aceh }\end{array}$ & $\begin{array}{l}\text { Corruption and } \\
\text { governance }\end{array}$ & $\begin{array}{l}\text { Road main- } \\
\text { tenance and } \\
\text { infrastructure }\end{array}$ & $\begin{array}{l}\text { Perceived negative impact of corruption and governance } \\
\text { on infrastructure repair }\end{array}$ \\
\hline James (2006) & $\begin{array}{l}\text { Australian National Uni- } \\
\text { versity report on corrup- } \\
\text { tion: discussion paper }\end{array}$ & Discussion & & $\begin{array}{l}\text { Corruption in } \\
\text { aid, weak gov- } \\
\text { ernance, rapid } \\
\text { decentralization, } \\
\text { civil conflict }\end{array}$ & Infrastructure & Theorizes negative association \\
\hline $\begin{array}{l}\text { Jayasuriya and Mc- } \\
\text { Cawley (2008) for } \\
\text { Asian Development } \\
\text { Bank }\end{array}$ & $\begin{array}{l}\text { Working paper exam- } \\
\text { ining aid delivery and } \\
\text { reconstruction after } \\
\text { tsunami }\end{array}$ & $\begin{array}{l}\text { Comments on aid delivery ar- } \\
\text { rangements and challenges of } \\
\text { designing reconstruction pro- } \\
\text { gram with recommendations }\end{array}$ & & $\begin{array}{l}\text { Poor aid qual- } \\
\text { ity leading to } \\
\text { increased cost } \\
\text { of labour, cost } \\
\text { increase in con- } \\
\text { struction goods, } \\
\text { lack of local } \\
\text { participation in } \\
\text { reconstruction }\end{array}$ & $\begin{array}{l}\text { Infrastructure, } \\
\text { poverty allevia- } \\
\text { tion }\end{array}$ & Discussed negative association (hypothesized? ) \\
\hline $\begin{array}{l}\text { Jayasuriya and Mc- } \\
\text { Cawley (2010). }\end{array}$ & $\begin{array}{l}\text { Book reviews tsunami } \\
\text { situation and aftermath } \\
\text { for Asian Development } \\
\text { Bank }\end{array}$ & $\begin{array}{l}\text { Literature review of disaster } \\
\text { policy response and economic } \\
\text { theory }\end{array}$ & & $\begin{array}{l}\text { Aid coordination, } \\
\text { labour market } \\
\text { changes, local } \\
\text { participation in } \\
\text { reconstruction, } \\
\text { weak governance }\end{array}$ & Infrastructure & Theory of negative association \\
\hline
\end{tabular}




\begin{tabular}{|c|c|c|c|c|c|c|}
\hline World Bank (2005) & $\begin{array}{l}\text { Situation report con- } \\
\text { ducted by BAPPENAS, } \\
\text { the Indonesian Govern- } \\
\text { ment and international } \\
\text { donors }\end{array}$ & Collection of reports & $\mathrm{N} / \mathrm{A}$ & Tsunami Impact & $\begin{array}{l}\text { Mortality, in- } \\
\text { frastructure, } \\
\text { health systems }\end{array}$ & $\begin{array}{l}\text { Negative impact on mortality, health system capacity, } \\
\text { infrastructure (exact detail reported throughout text of } \\
\text { paper) }\end{array}$ \\
\hline $\begin{array}{l}\text { World Health Orga- } \\
\text { nization (2005) }\end{array}$ & WHO news release & $\begin{array}{l}\text { Situation analysis of tsunami } \\
\text { recovery process }\end{array}$ & & Tsunami impact & $\begin{array}{l}\text { Infrastructure } \\
\text { and health sys- } \\
\text { tem capacity }\end{array}$ & $\begin{array}{l}\text { Negative impact observed (details reported throughout } \\
\text { text of paper) }\end{array}$ \\
\hline Ichwan (2011) & $\begin{array}{l}\text { Peer reviewed analysis of } \\
\text { Islamic Law in Aceh }\end{array}$ & $\begin{array}{l}\text { Authors analysis of legal pro- } \\
\text { ceedings and political process }\end{array}$ & & Influx of aid & Culture & $\begin{array}{l}\text { Author finds that the introduction of new religious } \\
\text { groups via aid efforts changed local religious interpre- } \\
\text { tations of Islam }\end{array}$ \\
\hline $\begin{array}{l}\text { Adiyoso and Kane- } \\
\text { gae (2013) }\end{array}$ & $\begin{array}{l}\text { Peer reviewed qualita- } \\
\text { tive study }\end{array}$ & $\begin{array}{l}\text { In-depth interviews and di- } \\
\text { rect observation }\end{array}$ & $\begin{array}{l}6 \text { Students and } 8 \text { commu- } \\
\text { nity members from Banda } \\
\text { Aceh }\end{array}$ & $\begin{array}{l}\text { Religious educa- } \\
\text { tion, culture and } \\
\text { disaster education }\end{array}$ & $\begin{array}{lr}\text { Disaster } & \text { pre- } \\
\text { paredness } & : \\
\text { Mortality } & \end{array}$ & $\mathrm{N} / \mathrm{A}$ \\
\hline Chang-Seng (2013) & $\begin{array}{l}\text { Peer reviewed } \\
\text { institutional-oriented } \\
\text { analysis framework }\end{array}$ & $\begin{array}{l}\text { Analysis of institutions and } \\
\text { governance related to devel- } \\
\text { opment of a tsunami early } \\
\text { warning system }\end{array}$ & & $\begin{array}{lr}\text { Civil conflict, } \\
\text { rapid decen- } \\
\text { tralization in } \\
\text { governance, cul- } \\
\text { ture }\end{array}$ & $\begin{array}{l}\text { Disaster pre- } \\
\text { paredness and } \\
\text { response-- } \\
\text { mortality }\end{array}$ & $\begin{array}{l}\text { Suggested association weak institutions were a result of } \\
\text { civil conflict and decentralization of government which } \\
\text { lead to limited disaster response capacity }\end{array}$ \\
\hline Grayman (2014) & $\begin{array}{l}\text { Peer reviewed ethno- } \\
\text { graphic case study }\end{array}$ & $\begin{array}{l}\text { Analysis of email archives be- } \\
\text { tween aid organization and } \\
\text { medical staff }\end{array}$ & & $\begin{array}{l}\text { Poor aid quality } \\
\text { and poor commu- } \\
\text { nication between } \\
\text { aid and health } \\
\text { staff (culture) }\end{array}$ & $\begin{array}{l}\text { Health system } \\
\text { quality }\end{array}$ & $\begin{array}{l}\text { Author hypothesizes negative association between use of } \\
\text { electronic communication and patient outcome }\end{array}$ \\
\hline Ismail et al. (2016) & $\begin{array}{l}\text { Peer reviewed as- } \\
\text { sessment of disaster } \\
\text { preparedness }\end{array}$ & Household descriptive survey & $\begin{array}{lrr}\text { Surveyed } & 827 & \text { random } \\
\text { households } & \text { in } & \text { Aceh } \\
\text { province } & & \end{array}$ & $\begin{array}{ll}\text { Disaster } & \text { pre- } \\
\text { paredness, } & \text { cul- } \\
\text { ture } & \end{array}$ & Mortality & $\begin{array}{l}26 \% \text { of participants had good knowledge of disaster pre- } \\
\text { paredness after the tsunami, far below the } 70 \% \text { target } \\
\text { which is hypothesized to have had a negative effect on } \\
\text { tsunami outcomes }\end{array}$ \\
\hline $\begin{array}{l}\text { Lovholt et al. } \\
\text { (2014) }\end{array}$ & $\begin{array}{l}\text { Peer reviewed analysis } \\
\text { of tsunami risk reduc- } \\
\text { tion } 10 \text { years after the } \\
\text { tsunami }\end{array}$ & Vulnerability assessment & Indonesia and Sri Lanka & $\begin{array}{l}\text { Culture and } \\
\text { disaster prepared- } \\
\text { ness governance } \\
\text { (tsunami aware- } \\
\text { ness, income } \\
\text { and employment, } \\
\text { ethnic group) }\end{array}$ & Mortality & $\begin{array}{l}\text { Concludes that improvements in preparedness have been } \\
\text { made implying that previously cultural and governance } \\
\text { factors hindered prevention }\end{array}$ \\
\hline
\end{tabular}




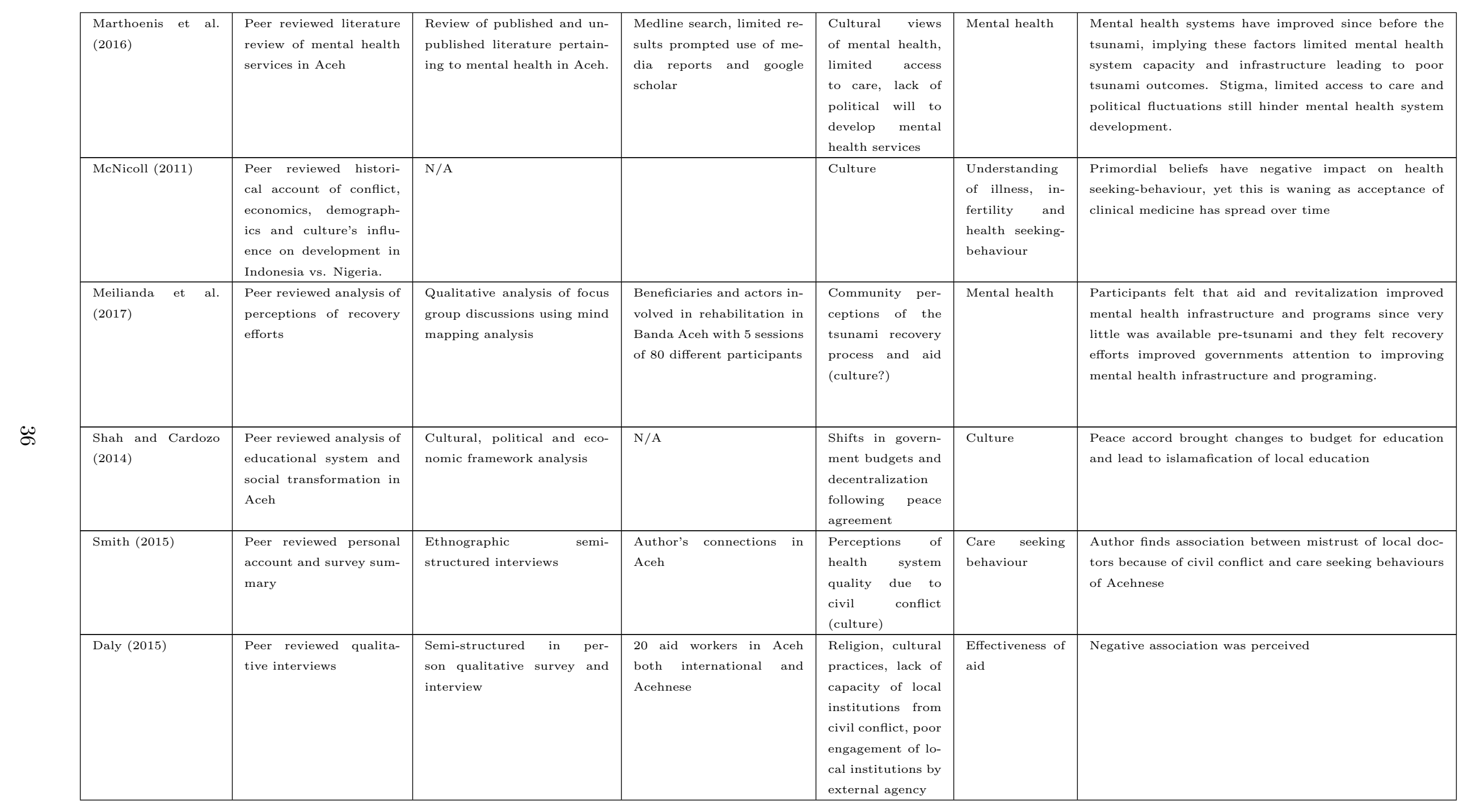




\begin{tabular}{|c|c|c|c|c|c|c|c|}
\hline & Thorburn (2009) & $\begin{array}{l}\text { Peer reviewed analysis of } \\
\text { recovery program impact }\end{array}$ & Program evaluation & $\mathrm{N} / \mathrm{A}$ & Aid & $\begin{array}{l}\text { Household in- } \\
\text { come, economic } \\
\text { re-development }\end{array}$ & $\begin{array}{l}\text { Almost three years after tsunami, many households re- } \\
\text { turned to pre-tsunami income levels which the author } \\
\text { attributes to food aid and subsidies, work programs and } \\
\text { livelihood assistance programs. Conversely, many busi- } \\
\text { ness start-up programs and agriculture programs had } \\
\text { mixed results as the author observes that economic de- } \\
\text { velopment program was supply-driven, not needs based. }\end{array}$ \\
\hline \multirow{6}{*}{ খ } & $\begin{array}{l}\text { Doocy (2007) for } \\
\text { the World Health } \\
\text { Organization }\end{array}$ & $\begin{array}{l}\text { Tsunami mortality re- } \\
\text { port }\end{array}$ & $\begin{array}{l}\text { Two-stage cluster } \\
\text { tsurvey of } \\
\text { tsunami-displaced house- } \\
\text { holds }\end{array}$ & $\begin{array}{l}\text { Surveys of } 1653 \text { households } \\
\text { across Aceh }\end{array}$ & $\begin{array}{l}\text { Location, demo- } \\
\text { graphics }\end{array}$ & $\begin{array}{l}\text { Mortality, pop- } \\
\text { ulation }\end{array}$ & $\begin{array}{l}\text { Highest mortality in } 0-9 y o \text { and } 70+y o \text {, mortality highest } \\
\text { in the west vs. east }\end{array}$ \\
\hline & $\begin{array}{l}\text { Frankenberg et al. } \\
(2011)\end{array}$ & $\begin{array}{l}\text { Peer reviewed analysis of } \\
\text { correlates of survival }\end{array}$ & $\begin{array}{l}\text { Analysis of population level } \\
\text { survey data with measure of } \\
\text { damage by location }\end{array}$ & $\begin{array}{l}43,606 \text { respondents liv- } \\
\text { ing in Aceh and North } \\
\text { Sumatra before and after } \\
\text { tsunami }\end{array}$ & $\begin{array}{l}\text { Demographics, lo- } \\
\text { cation }\end{array}$ & Mortality & $\begin{array}{l}\text { Children, older adults and females least likely to survive. } \\
\text { Mortality highest in those living within } 5 \mathrm{KM} \text { of coast } \\
(1 \text { in } 20 \text { died), within } 1 \mathrm{KM} \text { of coast }(1-2 \text { children and } \\
\text { females ( } 15-44 \text { yo }) \text { died and ( } 7 \text { of } 10 \text { older women died). } \\
\text { Men } 15-44 \text { yo }(1 \text { in } 4 \text { died). }\end{array}$ \\
\hline & Rofi et al. (2006) & $\begin{array}{l}\text { Peer reviewed analysis of } \\
\text { demographic impacts of } \\
\text { tsunami and assessment } \\
\text { of displaced households }\end{array}$ & $\begin{array}{l}\text { Household survey clustered } \\
\text { by internally displaced per- } \\
\text { son households and multi- } \\
\text { variate regression model for } \\
\text { risk of death analysis }\end{array}$ & $\begin{array}{l}\text { Survey of } 20 \text { clusters across } \\
\text { Aceh Barat and Naga Raya } \\
\text { including } 388 \text { households }\end{array}$ & $\begin{array}{l}\text { Location, demo- } \\
\text { graphic character- } \\
\text { istics }\end{array}$ & Mortality & $\begin{array}{l}\text { Mortality risk of females } 1.9 \text { [CI } 1.5-3.0] \text { times greater } \\
\text { than males, children under } 10 \text { and adults over } 60 \text { had } \\
2.3[1.6-3.4] \text { and } 3.1[1.9-4.9] \text { times the risk of mortal- } \\
\text { ity, fisheries based households were } 2.2[1.2-11.4] \text { times } \\
\text { more likely to have a household member die, of those } \\
\text { IDP household who settled, } 91.7 \% \text { [88.6-94.2] remained } \\
\text { in the same district }\end{array}$ \\
\hline & $\begin{array}{l}\text { Rassekh and San- } \\
\text { tosham (2014) }\end{array}$ & $\begin{array}{l}\text { Peer reviewed assess- } \\
\text { ment of care-seeking } \\
\text { practices in IDP's living } \\
\text { in barracks and non- } \\
\text { IDP's living in their } \\
\text { homes }\end{array}$ & $\begin{array}{l}\text { Cross-sectional cluster sam- } \\
\text { pling with stratification and } \\
\text { multiple logistic regression } \\
\text { analysis }\end{array}$ & $\begin{array}{l}31 \text { clusters of barracks } \\
\text { and non-IDP neighbour- } \\
\text { hoods with } 1295 \text { observa- } \\
\text { tions }\end{array}$ & $\begin{array}{l}\text { Maternal mortal- } \\
\text { ity and displace- } \\
\text { ment status }\end{array}$ & $\begin{array}{l}\text { Care seeking } \\
\text { behaviour, } \\
\text { child health }\end{array}$ & $\begin{array}{l}\text { Mother caretakers had } 1.88 \text { [CI } 1.04 ; 3.40] \text { times the odds } \\
\text { of seeking formal care for their sick children and those } \\
\text { who were not displaced had } 2.7 \text { [CI } 1.38 ; 5.44] \text { times the } \\
\text { odds of seeking formal care for their sick children }\end{array}$ \\
\hline & Du et al. (2012) & $\begin{array}{l}\text { Peer reviewed analysis } \\
\text { of children's' fears and } \\
\text { psychological experience } \\
\text { since the tsunami }\end{array}$ & $\begin{array}{l}\text { Multivariate logistical regres- } \\
\text { sion analysis of interviews } \\
\text { with displaced families }\end{array}$ & $\begin{array}{l}155 \text { child and parent dyads } \\
\text { from barracks and compar- } \\
\text { ison village within } 1 \mathrm{KM} \text { of } \\
\text { barrack }\end{array}$ & $\begin{array}{l}\text { Displacement and } \\
\text { residence in bar- } \\
\text { racks }\end{array}$ & Mental health & $\begin{array}{l}\text { Children from barracks were three times more likely to } \\
\text { report fear than children from villages Odds ratio of } \\
2.97(95 \% \text { CI } 1.00-8.85) \text {. }\end{array}$ \\
\hline & $\begin{array}{l}\text { Fan (2006) for the } \\
\text { World Bank }\end{array}$ & $\begin{array}{l}\text { Analysis of land rights } \\
\text { policy }\end{array}$ & & & $\begin{array}{l}\text { Governance, reli- } \\
\text { gion }\end{array}$ & $\begin{array}{l}\text { Housing quality } \\
\text { and poverty } \\
\text { disparities }\end{array}$ & $\begin{array}{l}\text { Perception that unequal land rights because of cultural, } \\
\text { religious, and legal precedents has a negative impact on } \\
\text { economic development, poverty and infrastructure }\end{array}$ \\
\hline
\end{tabular}




\subsubsection{Positive effect}

\begin{tabular}{|c|c|c|c|c|c|c|}
\hline Author & Study Type & Method & Population/ Study Size & Modifying Factor & $\begin{array}{l}\text { Outcome of In- } \\
\text { terest }\end{array}$ & Correlation or causal effect \\
\hline Chan et al. (2010) & $\begin{array}{l}\text { Peer reviewed field re- } \\
\text { port published in WHO } \\
\text { bulletin }\end{array}$ & $\begin{array}{l}\text { A balanced scorecard was cre- } \\
\text { ated and used to identify and } \\
\text { assess performance targets }\end{array}$ & $\begin{array}{l}7 \text { clinics and } 9 \text { accommoda- } \\
\text { tion centres across Aceh in } \\
2007\end{array}$ & $\begin{array}{l}\text { Aid quality and } \\
\text { assessment }\end{array}$ & $\begin{array}{l}\text { Quality of } \\
\text { health infras- } \\
\text { tructure }\end{array}$ & Positive association \\
\hline De Pee et al. (2007) & $\begin{array}{l}\text { Peer reviewed program } \\
\text { evaluation in bulletin of } \\
\text { UN university }\end{array}$ & $\begin{array}{l}\text { Descriptive analysis and pro- } \\
\text { gram evaluation }\end{array}$ & $\begin{array}{l}104,691 \text { children } 0-12 \text { in } \\
\text { transitional camps in Aceh } \\
\text { in Nias between January } \\
2005 \text { and April } 2006\end{array}$ & Food aid & $\begin{array}{l}\text { Nutritional sta- } \\
\text { tus and health } \\
\text { status of chil- } \\
\text { dren }\end{array}$ & $\begin{array}{l}\text { Authors correlate food aid to reduced anaemia and diar- } \\
\text { rhoea prevalence }\end{array}$ \\
\hline $\begin{array}{l}\text { Doocy et al. (2006) } \\
\text { for Mercy Corp }\end{array}$ & $\begin{array}{l}\text { Peer reviewed descrip- } \\
\text { tion and discussion of } \\
\text { program evaluation }\end{array}$ & $\begin{array}{l}\text { Review of monitoring data } \\
\text { and staff exit interviews }\end{array}$ & $\begin{array}{l}1,428 \text { randomly } \\
\text { Cash-for-Work program } \\
\text { participants in Banda } \\
\text { Aceh and Meulaboh }\end{array}$ & $\begin{array}{l}\text { Cash for work } \\
\text { programs (aid) }\end{array}$ & $\begin{array}{l}\text { Household } \\
\text { economics and } \\
\text { post-disaster } \\
\text { economic re- } \\
\text { covery } \\
\end{array}$ & Positive association \\
\hline Heger (2016) & PhD dissertation & $\begin{array}{l}\text { Synthetic control analy- } \\
\text { sis of economic outcomes } \\
\text { post-tsunami }\end{array}$ & $\begin{array}{l}\text { Analysis range in number } \\
\text { of districts in Aceh used }\end{array}$ & $\begin{array}{l}\text { Capital invest- } \\
\text { ment and aid }\end{array}$ & $\begin{array}{l}\text { Economic } \\
\text { Development }\end{array}$ & $\begin{array}{l}\text { GDP in districts with the most aid surpassed the coun- } \\
\text { terfactual across all models even after aid ended sig- } \\
\text { nalling creative destruction effect }\end{array}$ \\
\hline Lee et al. (2014) & $\begin{array}{l}\text { Peer reviewed impact as- } \\
\text { sessment of aid }\end{array}$ & $\begin{array}{l}\text { Cluster community survey; } \\
\text { multiple linear regression } \\
\text { analysis }\end{array}$ & $\begin{array}{l}598 \text { households in Banda } \\
\text { Aceh and Meulaboh sur- } \\
\text { veyed }\end{array}$ & Aid & $\begin{array}{l}\text { Development- } \\
\text { vulnerability } \\
\text { reduction, } \\
\text { poverty }\end{array}$ & $\begin{array}{l}\text { Standard of living, education and health facility satisfac- } \\
\text { tion increased significantly after tsunami believed to be } \\
\text { a result of receiving aid }\end{array}$ \\
\hline $\begin{array}{l}\text { Masyrafah and } \\
\text { McKeon (2008) for } \\
\text { Brookings Institute }\end{array}$ & Aid effectiveness report & $\begin{array}{l}\text { Analysis of types of aid given, } \\
\text { amounts of aid, pledged vs. } \\
\text { dispersed }\end{array}$ & $\mathrm{N} / \mathrm{A}$ & Aid & $\begin{array}{l}\text { Development- } \\
\text { vulnerability } \\
\text { reduction }\end{array}$ & $\begin{array}{l}\text { Aid has positive impact on sanitation, health facilities, } \\
\text { resource repair }\end{array}$ \\
\hline $\begin{array}{l}\text { Prasetiyawan et al. } \\
(2006)\end{array}$ & $\begin{array}{l}\text { Peer reviewed descrip- } \\
\text { tion and commentary on } \\
\text { proliferation of mental } \\
\text { health training }\end{array}$ & $\begin{array}{l}\text { Description and commentary } \\
\text { on the reach of mental health } \\
\text { programing }\end{array}$ & $\begin{array}{l}\text { Program administered to } \\
168 \text { GP's and } 277 \text { nurses in } \\
\text { Aceh and Sumatra Utara }\end{array}$ & $\begin{array}{l}\text { Professional } \\
\text { development } \\
\text { programs admin- } \\
\text { istered after the } \\
\text { tsunami, aid }\end{array}$ & $\begin{array}{l}\text { Improved di- } \\
\text { agnostic and } \\
\text { treatment prac- } \\
\text { tices for mental } \\
\text { health }\end{array}$ & $\begin{array}{l}\text { Author notes lack of mental health services pre-tsunami } \\
\text { and the positive results of professional development and } \\
\text { mental health capacity improvement to improve mental } \\
\text { health care }\end{array}$ \\
\hline $\begin{array}{l}\text { World Health Orga- } \\
\text { nization (2015) }\end{array}$ & $\begin{array}{l}\text { Book of lessons learned } \\
\text { and strategic planning } \\
\text { for the future of South } \\
\text { East Asia }\end{array}$ & $\begin{array}{l}\text { Compilation of various } \\
\text { reports and findings post- } \\
\text { tsunami }\end{array}$ & $\mathrm{N} / \mathrm{A}$ & $\begin{array}{l}\text { Disaster response, } \\
\text { aid }\end{array}$ & $\begin{array}{l}\text { Long-term } \\
\text { recovery }\end{array}$ & $\begin{array}{l}\text { Book emphasizes the importance of health on long-term } \\
\text { disaster recovery and highlights positive responses and } \\
\text { lessons learned }\end{array}$ \\
\hline Chang-Seng (2013) & $\begin{array}{l}\text { Peer reviewed analysis } \\
\text { of disaster risk prepared- } \\
\text { ness }\end{array}$ & $\begin{array}{l}\text { Governance concept and } \\
\text { framework conditions insti- } \\
\text { tutional analysis }\end{array}$ & $\mathrm{N} / \mathrm{A}$ & $\begin{array}{l}\text { Improved disaster } \\
\text { governance }\end{array}$ & $\begin{array}{l}\text { Improved } \\
\text { tsunami re- } \\
\text { silience }\end{array}$ & $\begin{array}{l}\text { Author concludes that learning from the tsunami has } \\
\text { changed disaster governance structures which will im- } \\
\text { prove future resilience }\end{array}$ \\
\hline
\end{tabular}




\begin{tabular}{|c|c|c|c|c|c|c|}
\hline $\begin{array}{l}\text { Syamsidik et al. } \\
(2017)\end{array}$ & $\begin{array}{l}\text { Peer reviewed review of } \\
\text { disaster governance } 10 \\
\text { years after the tsunami }\end{array}$ & $\begin{array}{l}\text { Survey of government em- } \\
\text { ployees and legislation }\end{array}$ & $\begin{array}{l}245 \text { respondents from Aceh } \\
\text { based organizations }\end{array}$ & $\begin{array}{l}\text { Governance } \\
\text { strengthening }\end{array}$ & $\begin{array}{l}\text { Vulnerability } \\
\text { reduction }\end{array}$ & $\begin{array}{l}\text { New guidance around disaster preparedness and im- } \\
\text { proved confidence of local stakeholder in policy has im- } \\
\text { proved integration of disaster risk maps with develop- } \\
\text { ment planning for future risk reduction }\end{array}$ \\
\hline $\begin{array}{l}\text { Beardsley and Mc- } \\
\text { Quinn (2009) }\end{array}$ & $\begin{array}{l}\text { Peer reviewed model for } \\
\text { understanding insurgent } \\
\text { groups motivation and } \\
\text { use of conflict }\end{array}$ & New typology proposed & Indonesia and Sri Lanka & $\begin{array}{l}\text { Estimated return } \\
\text { on investment, } \\
\text { dependence on } \\
\text { foreign relief aid }\end{array}$ & $\begin{array}{lr}\text { Behaviour } & \text { of } \\
\text { GAM, } & \text { civil } \\
\text { conflict }\end{array}$ & $\begin{array}{l}\text { GAM was incentivized to foster peace and end conflict } \\
\text { for their perceived longevity }\end{array}$ \\
\hline $\begin{array}{lll}\text { Gaillard } & \text { et } & \text { al. } \\
\text { (2008a) } & & \end{array}$ & $\begin{array}{l}\text { Peer reviewed framework } \\
\text { analysis of factors to se- } \\
\text { curing peace }\end{array}$ & $\begin{array}{l}\text { Review of disasters, conflicts } \\
\text { and diplomatic responses }\end{array}$ & $\begin{array}{l}\text { Aceh and other country } \\
\text { case studies }\end{array}$ & $\begin{array}{l}\text { Tsunami, pres- } \\
\text { sure from in- } \\
\text { ternational aid } \\
\text { organizations }\end{array}$ & $\begin{array}{l}\text { Conflict resolu- } \\
\text { tion }\end{array}$ & $\begin{array}{l}\text { The disaster played a positive role in encouraging peace } \\
\text { talks, author proposes that aid and international pres- } \\
\text { sure were an even greater catalyst for the ending of civil } \\
\text { conflict for the GAM }\end{array}$ \\
\hline $\begin{array}{lll}\text { Achmad } & \text { et } & \text { al. } \\
(2015) & & \end{array}$ & $\begin{array}{l}\text { Peer review analysis of } \\
\text { change and factor effect- } \\
\text { ing land use }\end{array}$ & $\begin{array}{l}\text { Land use geo-spacial map- } \\
\text { ping }\end{array}$ & Banda Aceh 2005-2009 & $\begin{array}{l}\text { Population den- } \\
\text { sity and location } \\
\text { of business center }\end{array}$ & City growth & $\begin{array}{l}\text { Built up areas in Banda Aceh increased } 90 \% \text { and were } \\
\text { positively impacted by population density and business } \\
\text { center growth }\end{array}$ \\
\hline Cas et al. (2014) & $\begin{array}{l}\text { Peer reviewed analysis } \\
\text { of correlation between } \\
\text { parental death and chil- } \\
\text { dren's wellbeing }\end{array}$ & $\begin{array}{l}\text { Ordinary least squares re- } \\
\text { gression with fixed effects }\end{array}$ & $\begin{array}{l}\text { 9-17 year olds living in } \\
\text { coastal communities } \mathrm{n}=737\end{array}$ & $\begin{array}{l}\text { Parental mortal- } \\
\text { ity }\end{array}$ & Child wellbeing & $\begin{array}{l}\text { If both parents died, } 9-14 \text { yo girls were } 58 \% \text { less likely to } \\
\text { still be enrolled in school } 5 \text { years later and girls } 15-17 \\
\text { were } 55 \% \text { less likely to be enrolled in school } 5 \text { years later }\end{array}$ \\
\hline $\begin{array}{l}\text { Frankenberg et al. } \\
\text { (2013b) }\end{array}$ & $\begin{array}{l}\text { Peer reviewed analysis } \\
\text { of the impact of socioe- } \\
\text { conomic status on re- } \\
\text { silience after natural dis- } \\
\text { aster }\end{array}$ & $\begin{array}{lr}\text { Multivariate } & \text { regression } \\
\text { analysis of } & \text { population- } \\
\text { representative } & \text { longitudinal } \\
\text { study } & \end{array}$ & $\begin{array}{l}3,813 \text { adults in areas heav- } \\
\text { ily damaged by tsunami }\end{array}$ & Education & $\begin{array}{l}\text { Morbidity, } \\
\text { mental health }\end{array}$ & $\begin{array}{l}\text { Education above primary level has some protective effect } \\
\text { for men, immediately after tsunami education did have } \\
\text { positive effect on spending vulnerability }\end{array}$ \\
\hline Phelps et al. (2011) & $\begin{array}{l}\text { Peer reviewed commen- } \\
\text { tary on opening of Aceh } \\
\text { post disaster }\end{array}$ & $\begin{array}{l}\text { Authors commentary based } \\
\text { on field work in Aceh and } \\
\text { Jakarta }\end{array}$ & $\mathrm{N} / \mathrm{A}$ & $\begin{array}{l}\text { Ending of civil } \\
\text { conflict }\end{array}$ & $\begin{array}{l}\text { International } \\
\text { investment }\end{array}$ & $\begin{array}{l}\text { Author argues that ending of the civil conflict reopened } \\
\text { trade routes, encouraged investment and united Aceh }\end{array}$ \\
\hline Nobles et al. (2015) & $\begin{array}{l}\text { Peer reviewed analysis of } \\
\text { fertility response to nat- } \\
\text { ural disaster shock }\end{array}$ & $\begin{array}{lll}\text { Multiple } & \text { linear } & \text { regression } \\
\text { analysis } & & \end{array}$ & $\begin{array}{l}\text { Nearly } 300 \text { communities } \\
\text { across Aceh }\end{array}$ & Fertility & Population & $\begin{array}{l}\text { For each one percentage point increase in community } \\
\text { mortality there is a } 1.2 \text { percentage point increase in prob- } \\
\text { ability of birth }\end{array}$ \\
\hline $\begin{array}{l}\text { Srinivas and Naka- } \\
\text { gawa (2008) }\end{array}$ & $\begin{array}{l}\text { Peer reviewed environ- } \\
\text { mental analysis }\end{array}$ & $\begin{array}{l}\text { Observations of environmen- } \\
\text { tal impact of tsunami }\end{array}$ & Indonesia & $\begin{array}{l}\text { Conservation } \\
\text { and ecological } \\
\text { preservation } \\
\text { pre-disaster }\end{array}$ & $\begin{array}{l}\text { Development- } \\
\text { housing, } \\
\text { poverty }\end{array}$ & $\begin{array}{l}\text { Author notes that damage from natural disasters de- } \\
\text { stroys infrastructure, livelihoods and sanitation systems } \\
\text { and notes that in coastal areas that were protected and } \\
\text { where development was not close to the shore line did } \\
\text { better, recommends improved eco-sustainable develop- } \\
\text { ment practices }\end{array}$ \\
\hline
\end{tabular}




\subsubsection{Undetermined effect}

\begin{tabular}{|c|c|c|c|c|c|c|}
\hline Author & Study Type & Method & Population/ Study Size & Modifying Factor & $\begin{array}{l}\text { Outcome of In- } \\
\text { terest }\end{array}$ & Correlation or causal effect \\
\hline $\begin{array}{l}\text { Gaillard et al. } \\
\text { (2008b) }\end{array}$ & $\begin{array}{l}\text { Peer reviewed discussion } \\
\text { of ethnic groups customs } \\
\text { and disaster experiences }\end{array}$ & $\begin{array}{l}\text { Community surveys and } \\
\text { framework analysis }\end{array}$ & 120 Face to face interviews & Culture & Mortality & $\begin{array}{l}\text { Mortality varied dramatically by ethnic group, survival } \\
\text { depended on historical experience and education of dis- } \\
\text { asters, location to coast and relative freedoms of women }\end{array}$ \\
\hline Jauhola (2010) & $\begin{array}{l}\text { Peer reviewed analysis } \\
\text { of gender mainstreaming } \\
\text { policies and advocacy }\end{array}$ & $\begin{array}{l}\text { Analysis and framework of } \\
\text { gender normativity in Aceh }\end{array}$ & & $\begin{array}{l}\text { Gender roles, reli- } \\
\text { gion, government }\end{array}$ & $\begin{array}{l}\text { Advocacy } \\
\text { capacity }\end{array}$ & $\begin{array}{l}\text { Author argues that gender advocacy needs to include } \\
\text { economic and political oppression in its interpretation } \\
\text { of gender biases and violence }\end{array}$ \\
\hline Kenny (2007) & $\begin{array}{l}\text { Peer reviewed analysis } \\
\text { of types of capacity } \\
\text { building available post- } \\
\text { tsunami }\end{array}$ & $\begin{array}{l}\text { Author offers different frame- } \\
\text { works through which to view } \\
\text { capacity building }\end{array}$ & $\mathrm{N} / \mathrm{A}$ & Aid & $\begin{array}{l}\text { Community } \\
\text { development, } \\
\text { training, recon- } \\
\text { struction }\end{array}$ & $\begin{array}{l}\text { Author offers mixed reviews of capacity building to meet } \\
\text { outcomes of interest }\end{array}$ \\
\hline $\begin{array}{l}\text { Muriuki et al. } \\
\text { (2012) for Mentor } \\
\text { Initiative }\end{array}$ & $\begin{array}{l}\text { Peer reviewed research } \\
\text { report of malaria preva- } \\
\text { lence }\end{array}$ & Malaria prevalence surveys & $\begin{array}{l}11,763 \text { individuals in } 5 \\
\text { coastal districts of Aceh }\end{array}$ & Malaria & Morbidity & $\begin{array}{l}\text { Study finds an epidemic did not occur, but given that } \\
\text { pre-tsunami data is not available study can not draw a } \\
\text { conclusion about tsunami effect }\end{array}$ \\
\hline Oktari et al. (2017) & $\begin{array}{l}\text { Peer reviewed analysis } \\
\text { of disaster management } \\
\text { budget post-tsunami }\end{array}$ & $\begin{array}{l}\text { Literature review and bud- } \\
\text { get analysis based on recom- } \\
\text { mendations from interviewed } \\
\text { stakeholders }\end{array}$ & $\begin{array}{l}\text { Banda Aceh local budgets } \\
\text { from 2007-2015 }\end{array}$ & $\begin{array}{l}\text { Government bud- } \\
\text { gets }\end{array}$ & $\begin{array}{l}\text { Vulnerability } \\
\text { reduction }\end{array}$ & $\begin{array}{l}\text { Legal frameworks have improved, disaster management } \\
\text { budgets have improved, yet study cannot draw conclu- } \\
\text { sion on quality of investments }\end{array}$ \\
\hline $\begin{array}{l}\text { Régnier et al. } \\
\text { (2008) }\end{array}$ & $\begin{array}{l}\text { Peer reviewed investiga- } \\
\text { tion into livelihood re- } \\
\text { covery }\end{array}$ & Case study analysis & Aceh v. Tamil Nadu India & Aid & $\begin{array}{l}\text { Economic } \\
\text { recovery }\end{array}$ & $\begin{array}{l}\text { Only a few organizations could deliver economic recovery } \\
\text { and most were chaotic unorganized aid efforts }\end{array}$ \\
\hline Steinberg (2007) & $\begin{array}{l}\text { Peer reviewed report on } \\
\text { housing reconstruction }\end{array}$ & $\begin{array}{l}\text { Review of experience of im- } \\
\text { plementing housing programs }\end{array}$ & Aceh and Nias & Aid & $\begin{array}{l}\text { Housing rede- } \\
\text { velopment }\end{array}$ & $\begin{array}{l}\text { Building back better initiative will take more time to } \\
\text { incorporate the views of effected communities and has } \\
\text { both benefits and drawbacks }\end{array}$ \\
\hline $\begin{array}{lll}\text { Sudomo } & \text { et } & \text { al. } \\
(2010) & & \end{array}$ & $\begin{array}{l}\text { Peer reviewed report of } \\
\text { malaria prevalence }\end{array}$ & $\begin{array}{l}\text { Village and school-based sur- } \\
\text { veys of malaria prevalence }\end{array}$ & Simeulue & Malaria & Morbidity & $\begin{array}{l}\text { Malaria may have been endemic before tsunami, aid ef- } \\
\text { forts helped to control malaria and island remains on its } \\
\text { way to eradication. Study does not offer evidence on } \\
\text { change in morbidity }\end{array}$ \\
\hline $\begin{array}{l}\text { Thormar et al. } \\
\text { (2014) }\end{array}$ & $\begin{array}{l}\text { Peer reviewed analysis } \\
\text { of longitudinal study of } \\
\text { PTSD in relief volun- } \\
\text { teers }\end{array}$ & $\begin{array}{l}\text { Impact of Event Scale sur- } \\
\text { vey conducted at } 6 \text { and } 18 \\
\text { months post-tsunami }\end{array}$ & $\begin{array}{l}506 \text { Indonesian Red Cross } \\
\text { volunteers }\end{array}$ & Volunteering & Morbidity & $\begin{array}{l}\text { Finds some evidence that volunteers have higher PTSD } \\
\text { prevalence than professional workers, but notes that } \\
\text { methodological differences hinder this association }\end{array}$ \\
\hline Uscher-Pines (2009) & $\begin{array}{l}\text { Peer } \quad \text { review } r \text { system- } \\
\text { atic literature review } \\
\text { of health effects of } \\
\text { relocation }\end{array}$ & Systematic literature review & $\begin{array}{l}24 \text { articles reviewed from } 5 \\
\text { databases plus google }\end{array}$ & Relocation & Morbidity & $\begin{array}{l}\text { Literature review finds mixed evidence of the impact of } \\
\text { relocation on health and health seeking behaviour }\end{array}$ \\
\hline
\end{tabular}




\begin{tabular}{|l|l|l|l|l|l|l|}
\hline $\begin{array}{l}\text { Waizenegger and } \\
\text { Hyndman (2010) }\end{array}$ & $\begin{array}{l}\text { Peer reviewed analysis of } \\
\text { peace process for multi- } \\
\text { ple stakeholders }\end{array}$ & $\begin{array}{l}\text { Interviews and in-field re- } \\
\text { search }\end{array}$ & $\begin{array}{l}\text { Field work in Aceh and } \\
\text { unidentified number of } \\
\text { interview with stake- } \\
\text { holders, interview of 14 } \\
\text { ex-combatants }\end{array}$ & Civil conflict & $\begin{array}{l}\text { Aid to tsunami survivors was greater than for conflict } \\
\text { survivors which could hinder future peace }\end{array}$ \\
\hline Zeccola (2011) & $\begin{array}{l}\text { Peer reviewed analysis of } \\
\text { humanitarian action }\end{array}$ & $\begin{array}{l}\text { Authors commentary from } \\
\text { working in Aceh }\end{array}$ & $\begin{array}{l}\text { Aid, civil conflict, } \\
\text { governance }\end{array}$ & $\begin{array}{l}\text { Reconstruction } \\
\text { Author argues need for donor flexibility in changing hu- } \\
\text { manitarian contexts as changing context poses new chal- } \\
\text { lenges for aid delivery amid political contexts }\end{array}$ \\
\hline
\end{tabular}


6.3 Appendix 3: Sample of the DHS and estimation of mortality

\begin{tabular}{|l|l|}
\hline Year & $\begin{array}{l}\text { Number of chil- } \\
\text { dren }\end{array}$ \\
\hline 1990 & 9,364 \\
1991 & 9,235 \\
1992 & 10,307 \\
1993 & 10,324 \\
1994 & 10,753 \\
1995 & 11,987 \\
1996 & 12,578 \\
1997 & 11,697 \\
1998 & 12,084 \\
1999 & 13,178 \\
2000 & 15,024 \\
2001 & 13,664 \\
2002 & 13,485 \\
2003 & 11,353 \\
2004 & 10,899 \\
2005 & 10,831 \\
2006 & 11,127 \\
2007 & 9,592 \\
2008 & 7,355 \\
2009 & 7,268 \\
2010 & 7,324 \\
2011 & 7,564 \\
2012 & 5,177 \\
2013 & 3,674 \\
2014 & 3,550 \\
2015 & 3,552 \\
2016 & 3,671 \\
2017 & 2,301 \\
\hline Total & 258,918 \\
\hline & \\
\hline
\end{tabular}




\subsection{Appendix 4: Inclusion of covariates}

Using IDRP data: Covariates include the proportion of births attended by skilled health worker, the GDP on construction sector, access to safe water, access to safe sanitation, net enrolment ratio, total GDP, total population and total revenue of the province. The data set contains a total of 19 provinces (18 donor provinces) and 17 years including 8 pre-treatment years. We conduct the synthetic control by including the level of pre-treatment outcomes in 1996, 1999 and 2003 .

Under-5 mortality (per 1,000 live births)

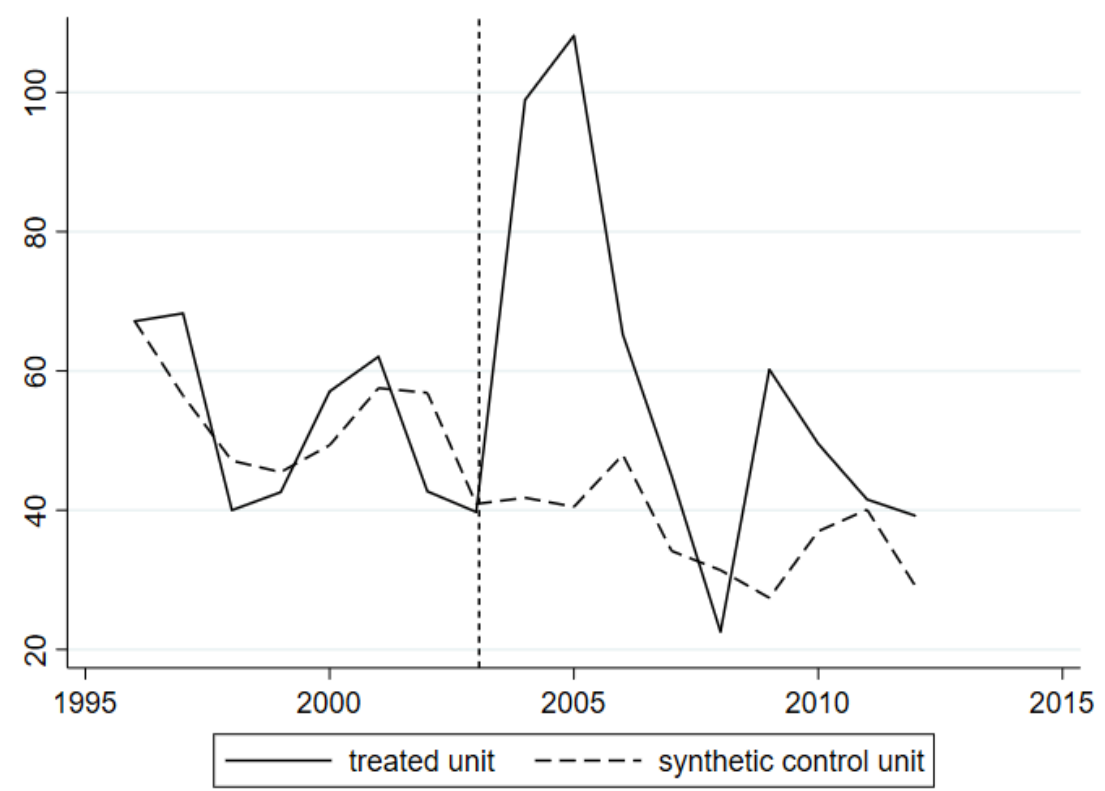

Under-1 mortality (per 1,000 live births)

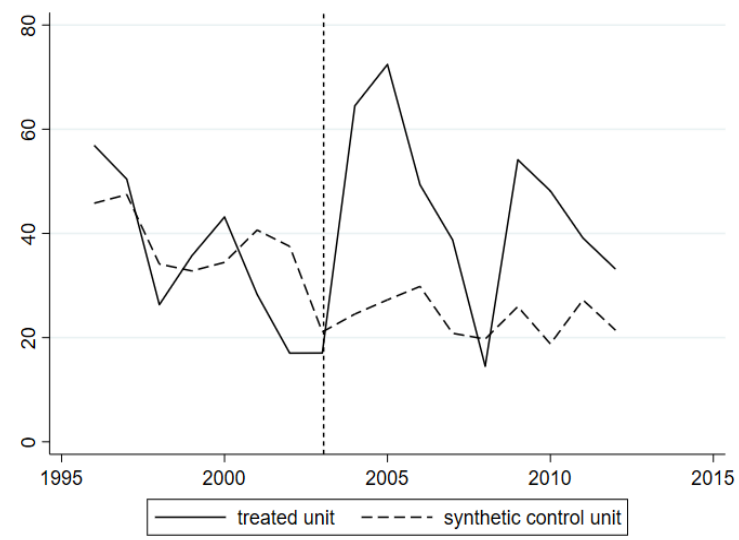

1-4 years old mortality (per 1,000 live births)

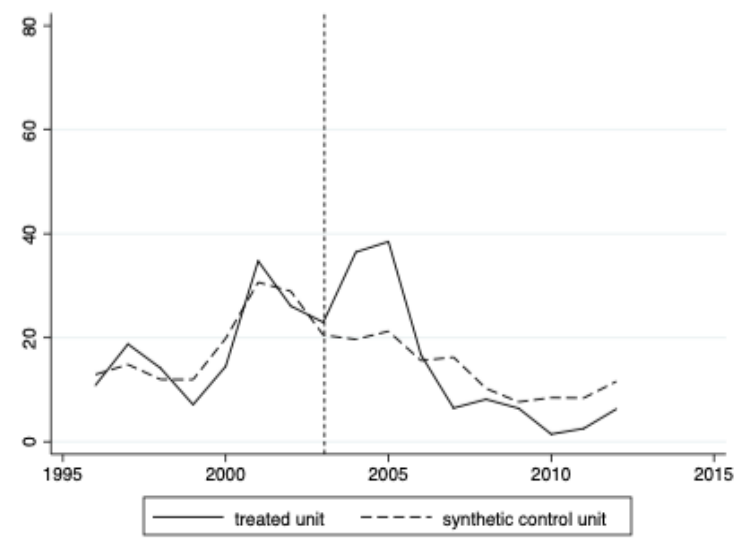


Using DHS data: Covariates include the access to drinking water, antenatal care, births attended by skilled health worker, tetanus immunisation coverage, home delivery. Data cover the period of 1992-2017 and 25 provinces (24 donor provinces). We conduct the synthetic control by including the level of pre-treatment outcomes in 1992, 1997 and 2003.

Under-5 mortality (per 1,000 live births)

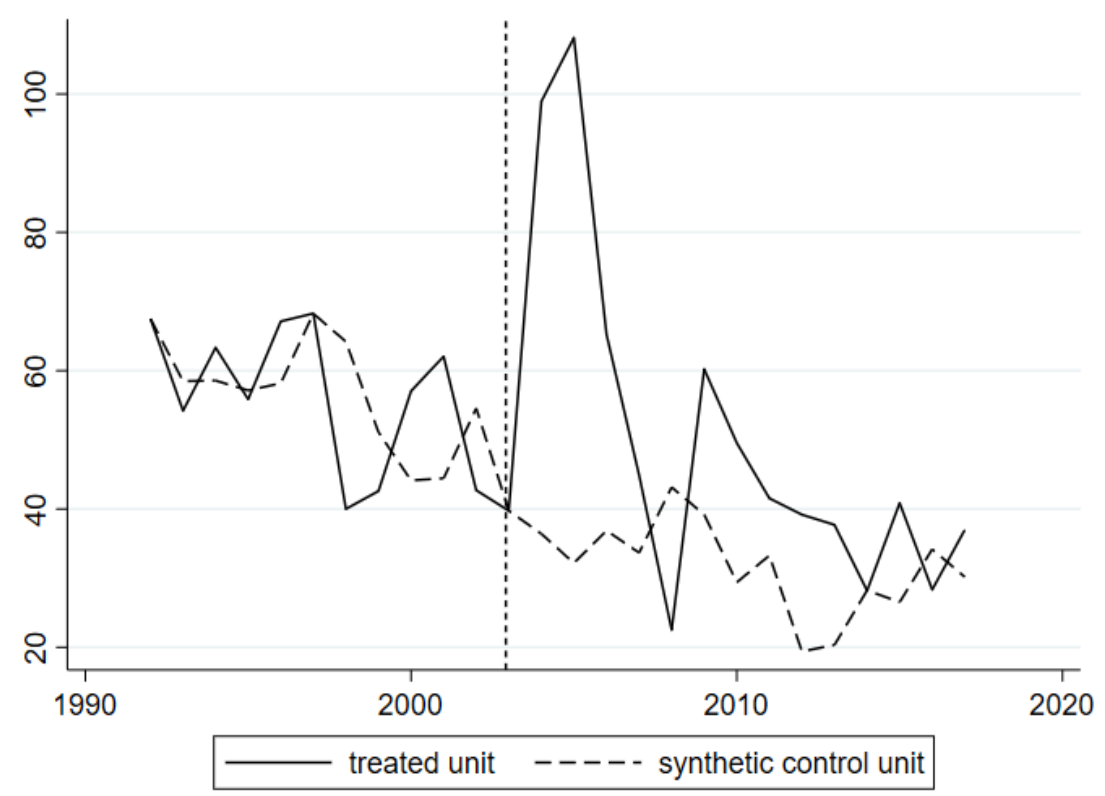

Under-1 mortality (per 1,000 live births)

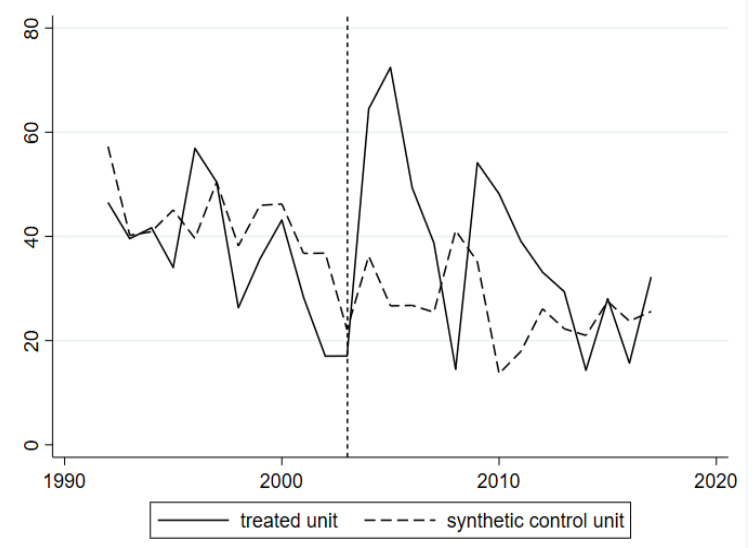

1-4 years old mortality (per 1,000 live births)

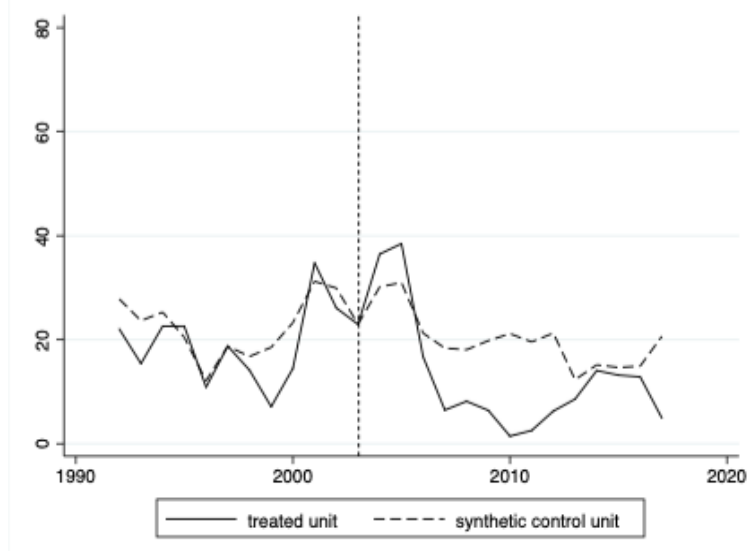




\subsection{Appendix 5: Donor Pool Weights and RMSPE Tables}

\begin{tabular}{|c|c|c|c|}
\hline & $\begin{array}{l}\text { Under-5 } \\
\text { mortality }\end{array}$ & $\begin{array}{l}\text { Under-1 } \\
\text { mortality }\end{array}$ & $\begin{array}{l}1-4 \text { year old } \\
\text { mortality }\end{array}$ \\
\hline West sumatra & 0 & 0 & 0 \\
\hline Riau & 0 & .134 & 0 \\
\hline Jambi & 0 & .165 & .359 \\
\hline South sumatra & 0 & 0 & 0 \\
\hline Bengkulu & .09 & 0 & 0 \\
\hline Lampung & 0 & 0 & 0 \\
\hline Jakarta & 0 & .281 & 0 \\
\hline Central java & 0 & 0 & 0 \\
\hline Yogyakarta & .363 & .189 & 0 \\
\hline East java & 0 & 0 & 0 \\
\hline West Java & 0 & 0 & 0 \\
\hline Bali & .148 & 0 & .249 \\
\hline West nusa tenggara & 0 & 0 & 0 \\
\hline East nusa tenggara & 0 & 0 & 0 \\
\hline West kalimantan & 0 & 0 & 0 \\
\hline Central kalimantan & .015 & 0 & .091 \\
\hline South kalimantan & 0 & .019 & 0 \\
\hline East kalimantan & .25 & .212 & 0 \\
\hline Central sulawesi & 0 & 0 & 0 \\
\hline Southeast sulawesi & 0 & 0 & 0 \\
\hline North sulawesi & .023 & 0 & 0 \\
\hline South sulawesi & 0 & 0 & 0 \\
\hline Maluku & 0 & 0 & .118 \\
\hline Papua & .111 & 0 & .183 \\
\hline Total & 1 & 1 & 1 \\
\hline RMSPE & 7.140 & 8.045 & 4.163 \\
\hline
\end{tabular}




\subsection{Appendix 6a: Placebo Test Graphs (untrimmed)}

Under-5 mortality (per 1,000 live births)

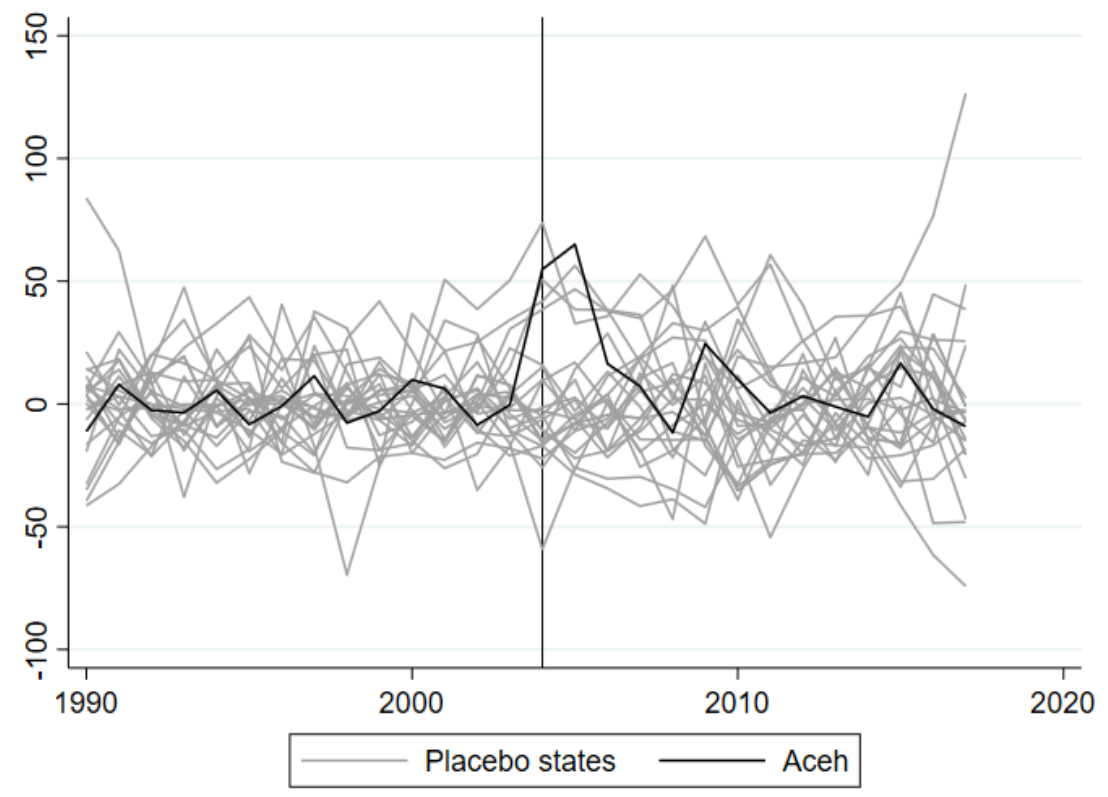

Under-1 mortality (per 1,000 live births)

1-4 years old mortality (per 1,000 live births)
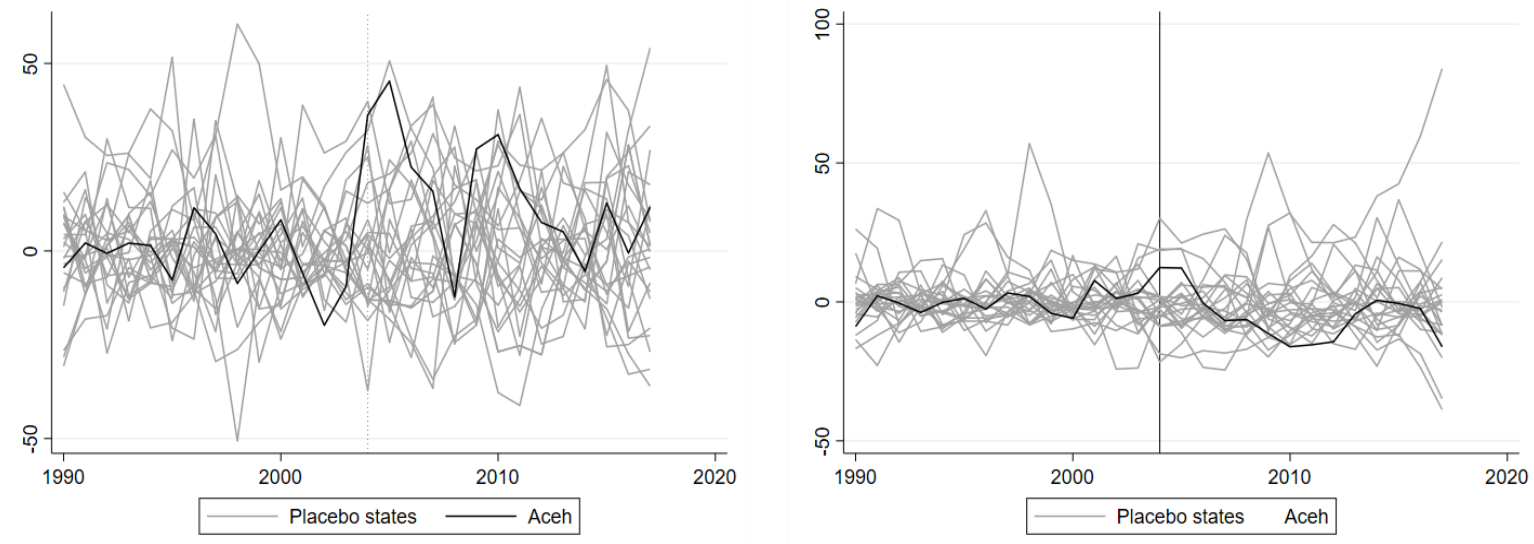


\subsection{Appendix 6b: Placebo Test Graphs (trimmed)}

Under-5 mortality (per 1,000 live births)

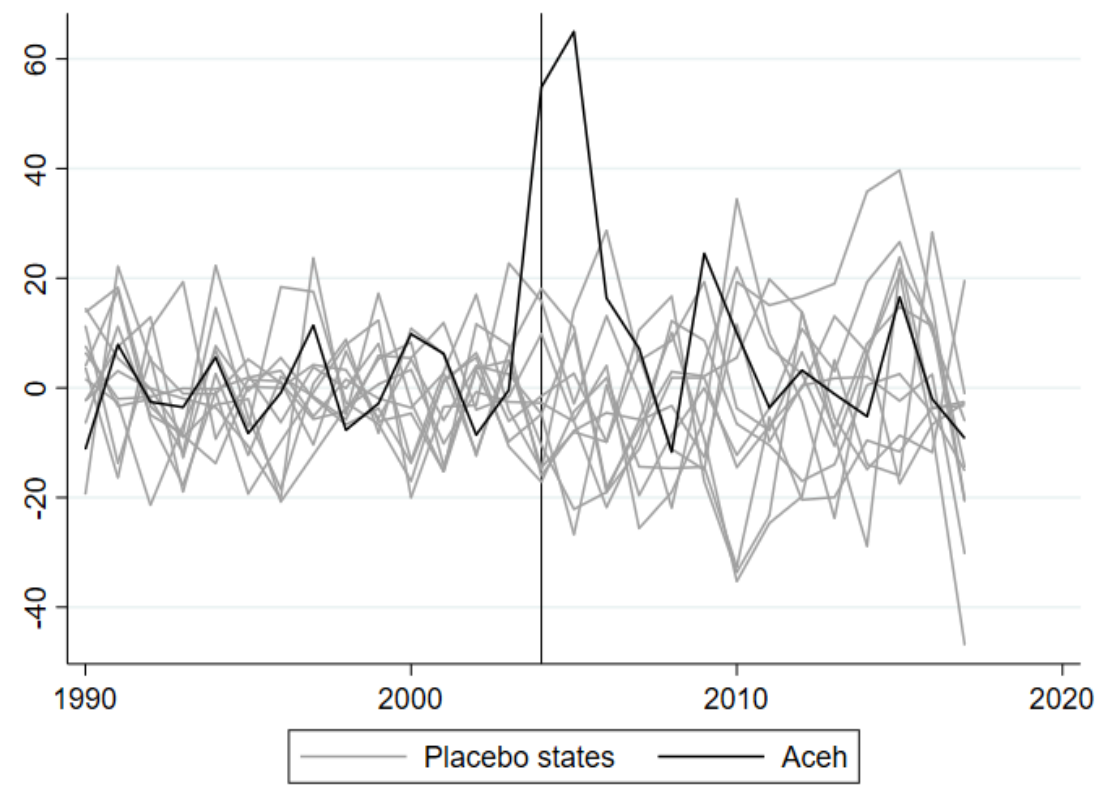

Under-1 mortality (per 1,000 live births)

1-4 years old mortality (per 1,000 live births)
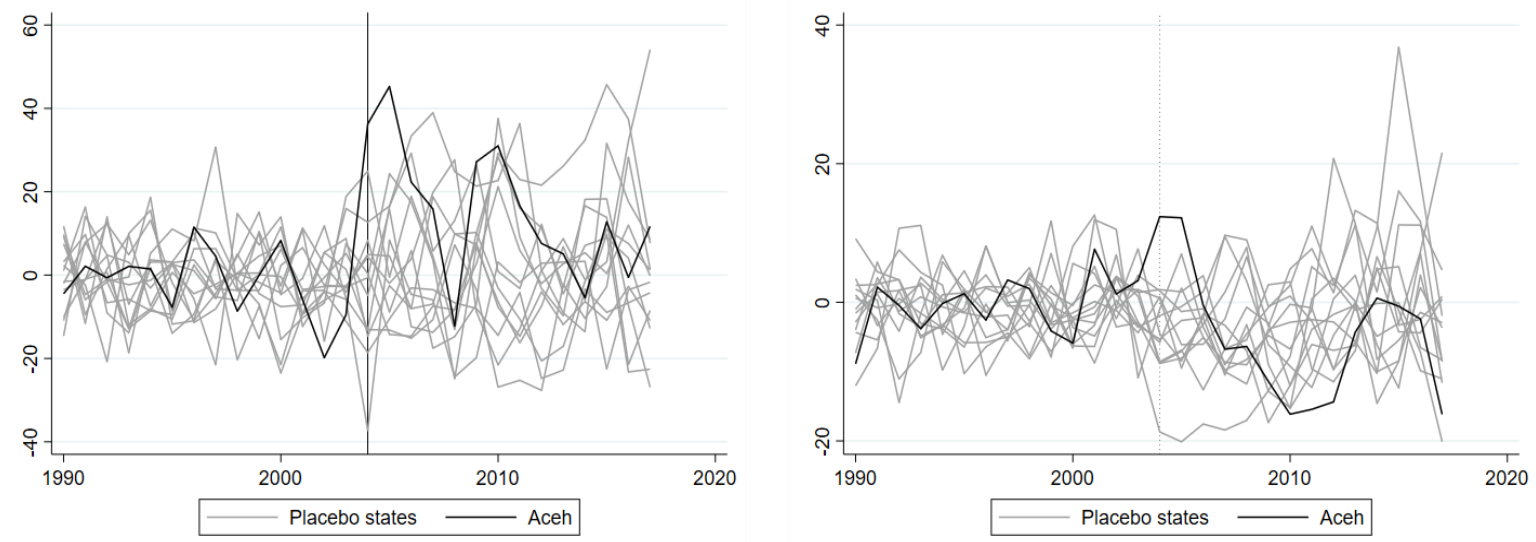


\subsection{Appendix 7a: Backdating analyses}

Under-5 mortality (per 1,000 live births)

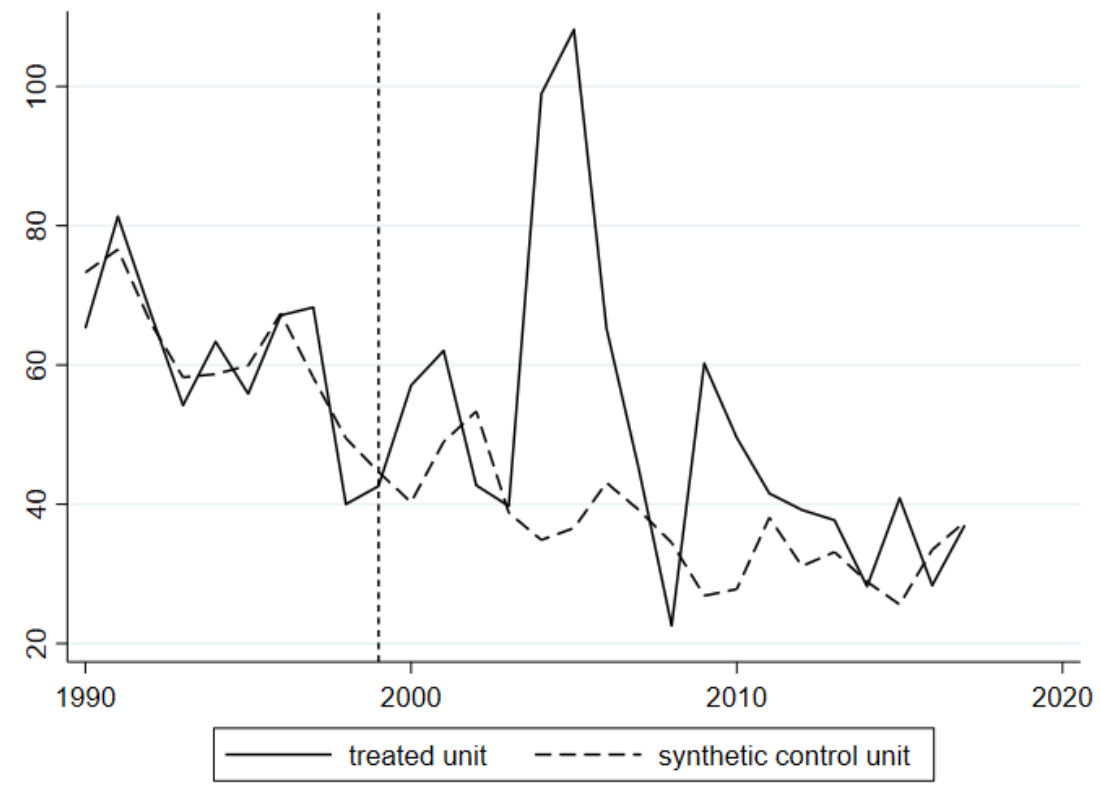

Under-1 mortality (per 1,000 live births)

1-4 years old mortality (per 1,000 live births)
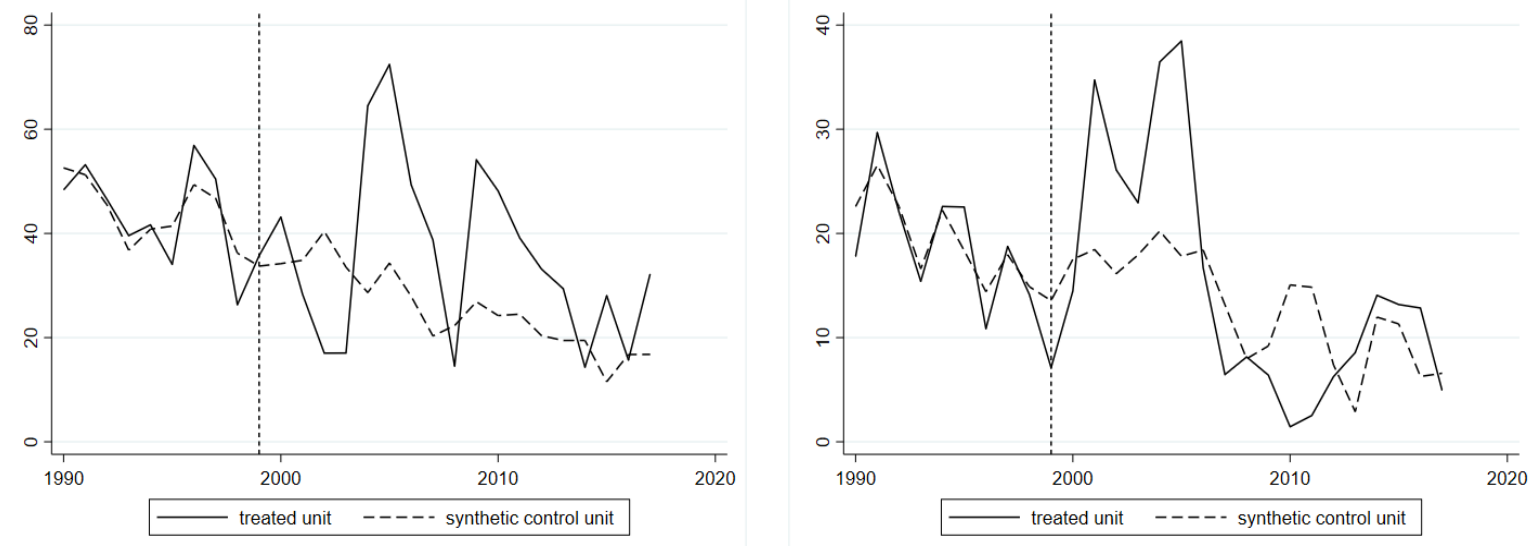


\subsection{Appendix 7b: Leave-out analyses}

Under-5 mortality (per 1,000 live births)

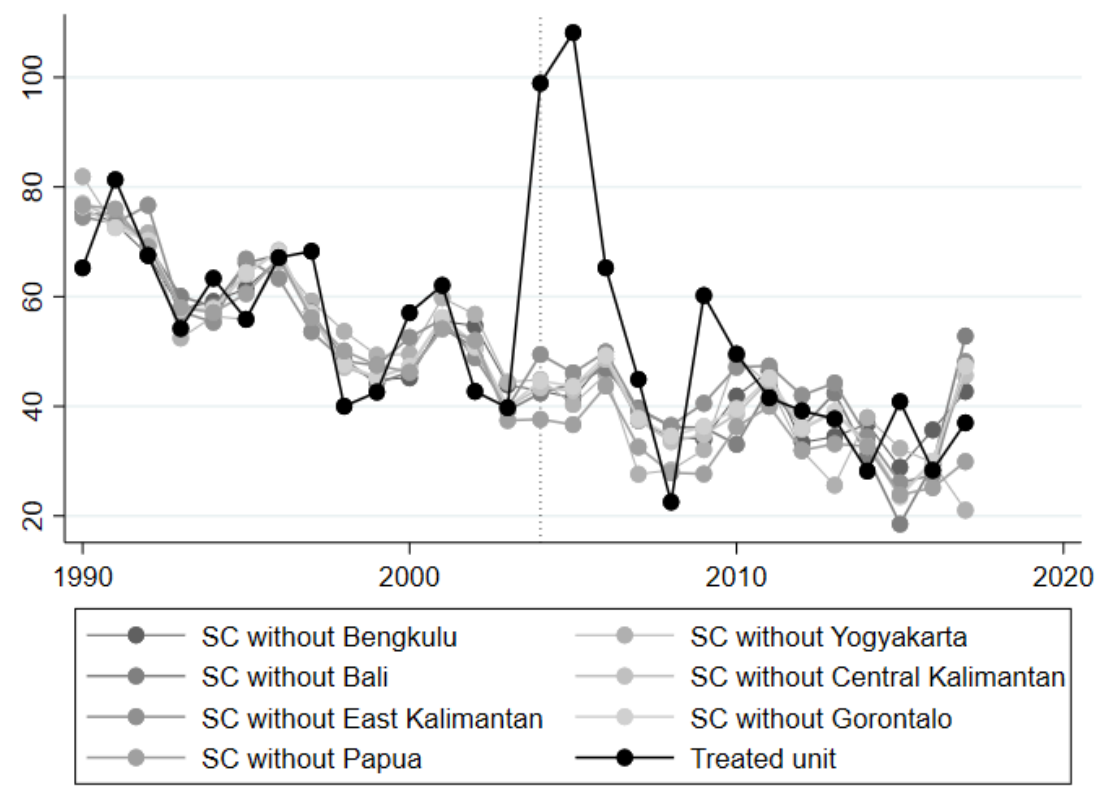

Under-1 mortality (per 1,000 live births)

1-4 years old mortality (per 1,000 live births)
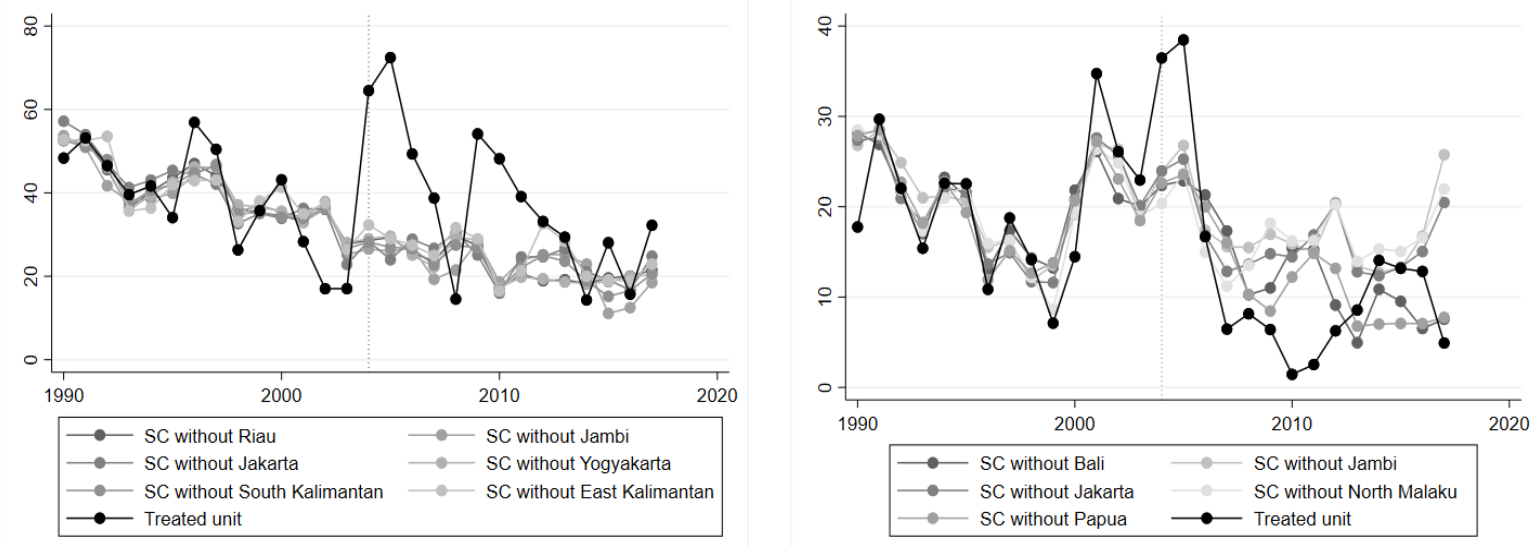


\section{$7 \quad$ References}

ABADIE, A., DiAmOND, A. \& HAINMUELlER, J. 2010. Synthetic Control Methods for Comparative Case Studies: Estimating the Effect of California's Tobacco Control Program. Journal of the American Statistical Association, 105, 493-505.

ABADIE, A. \& GARDEAZABAL, J. 2003. The Economic Costs of Conflict: A Case Study of the Basque Country. American Economic Review, 93, 113-132.

ABADIE, A. 2019. Using Synthetic Controls: Feasibility, Data Requirements, and Methodological Aspects. MIT working paper.

ACHMAD, A., HASYIM, S., DAHLAN, B. \& AULIA, D. N. 2015. Modeling of urban growth in tsunamiprone city using logistic regression: Analysis of Banda Aceh, Indonesia. Applied Geography, 62, 237-246.

ADIYOSO, W. \& KANEGAE, H. 2013. The preliminary study of the role of islamic teaching in the disaster risk reduction (a qualitative case study of Banda Aceh, Indonesia). In: UTAMA, N. A., MCLELLAN, B. C., TARNO, H., HAMZAh, S., BRAmANTORO, A., APIP, TRIHARTONO, A., SURYATMOJO, H., WIDODO, S. \& HIMMI, S. K. (eds.) 3rd International Conference on Sustainable Future for Human Security, Sustain 2012.

AGUSTINI, E. N., ASNIAR, I. \& MATSUO, H. 2011. The prevalence of long-term post-traumatic stress symptoms among adolescents after the tsunami in Aceh. Journal of Psychiatric \& Mental Health Nursing, 18, 543-549.

AIDA, J., HikiChi, H., MATSUYAmA, Y., SATO, Y., TSUbOYA, T., TABUCHI, T., KOYAmA, S., SUBRAMANIAN, S., KONDO, K. \& OSAKA, K. 2017. Risk of mortality during and after the 2011 Great East Japan Earthquake and Tsunami among older coastal residents. Scientific reports, 7, 16591.

ARMENIAN, H. K., MELKONIAN, A. K. \& HOVANESIAN, A. P. 1998. Long term mortality and morbidity related to degree of damage following the 1988 earthquake in Armenia. American journal of epidemiology, 148, 1077-1084.

ATHukORAlA, P.-C. \& RESOSUDARMO, B. P. 2005. The Indian Ocean Tsunami: Economic Impact, Disaster Management, and Lessons. Asian Economic Papers, 4, 1-39.

ATHUKORALA, P. C. 2012. Indian Ocean Tsunami: Disaster, Generosity and Recovery. Asian Economic Journal, 26, 211-231.

BEARDSLEY, K. \& MCQUINN, B. 2009. Rebel Groups as Predatory Organizations. Journal of Conflict Resolution, 53, 624-645.

CARUSO, G. \& MILLER, S. 2015. Long run effects and intergenerational transmission of natural disasters: 
A case study on the 1970 Ancash Earthquake. Journal of development Economics, 117, 134-150.

CAS, A. G., FRAnkEnBERG, E., SURIASTINI, W. \& THOMAS, D. 2014. The Impact of Parental Death on Child Well-being: Evidence From the Indian Ocean Tsunami. Demography, 51, 437-457.

CHAN, G. J., PARCO, K. B., SIHOMBInG, M. E., TREDWELL, S. P. \& O'ROURKE, E. J. 2010. Improving health services to displaced persons in Aceh, Indonesia: a balanced scorecard. World Health Organization. Bulletin of the World Health Organization, 88, 709-12.

CHANG-SENG, D. 2013. Tsunami resilience: Multi-level institutional arrangements, architectures and system of governance for disaster risk preparedness in Indonesia. Environmental Science \& Policy, 29, 57-70.

CHEN, B., HALLIDAY, T. J. \& FAN, V. Y. 2016. The impact of internal displacement on child mortality in post-earthquake Haiti: a difference-in-differences analysis. International journal for equity in health, $15,114$.

DALY, P. 2015. Embedded wisdom or rooted problems? Aid workers' perspectives on local social and political infrastructure in post-tsunami Aceh. Disasters, 39, 232-257.

DATAR, A., LIU, J., LINNEMAYR, S. \& STECHER, C. 2013. The impact of natural disasters on child health and investments in rural India. Social Science \& Medicine, 76, 83-91.

DE JONG, K., PROSSER, S. \& FORD, N. 2005. Addressing psychosocial needs in the aftermath of the tsunami - MSF shares its observations from its programme in Aceh, Indonesia. Plos Medicine, 2, 486-488.

DE PEE, S., MOENCH-PFANNER, R., MARTINI, E., ZLOTKIN, S. H., DARNTON-HILL, I. \& BLOEM, M. W. 2007. Home fortification in emergency response and transition programming: Experiences in Aceh and Nias, Indonesia. Food and Nutrition Bulletin, 28, 189-197.

DOOCY, S., GABRIEL, M., COLlins, S., ROBInSOn, C. \& STEVEnSON, P. 2006. Implementing cash for work programmes in post-tsunami Aceh: experiences and lessons learned. Disasters, 30, 277-296.

DOOCY, S., ROBInSON, C., MOODIE, C. \& BURnhAM, G. 2009. Tsunami-related injury in Aceh Province, Indonesia. Global Public Health, 4, 205-214.

DOOCY, S. R., ABDUR; MOODIE, CLAIRE; SPRING, ERIC; BRADLEY, SCOTT; BURNHAMA,GILBERT; ROBINSONA, CORTLAND 2007. Tsunami mortality in Aceh Province, Indonesia. Bulletin of the World Health Organization, 85, 273-278.

DU, Y. B., LEE, C. T., ChristinA, D., BElfER, M. L., BETAnCOURT, T. S., O'ROURKE, E. J. \& PALFREY, J. S. 2012. The living environment and children's fears following the Indonesian tsunami. Disasters, 
$36,495-513$.

FAN, L. 2006. THE STRUGGLE FOR LAND RIGHTS IN POST-TSUNAMI AND POST-CONFLICT ACEH, INDONESIA The World Bank, Land Policies and Legal Empowerment of the Poor FRANKENBERG, E., Friedman, J., Gillespie, T., InGWERSEN, N., PYNOOS, R., RIFAi, I. U., SiKOKI, B., STEINBERG, A., SUMANTRI, C., SURIASTINI, W. \& THOMAS, D. 2008. Mental health in Sumatra after the tsunami. American Journal of Public Health, 98, 1671-1677.

FERMAN B., PINTO C., POSSEBOM V. 2020. Cherry picking with synthetic controls. Journal of Policy Analysis and Management 39(2), 510-532.

FRANKENBERG, E., FRIEDMAN, J., INGWERSEN, N. \& THOMAS, D. Linear child growth after a natural disaster: a longitudinal study of the effects of the 2004 Indian Ocean tsunami. The Lancet, 389, S21.

FRANKENBERG, E., FRIEDMAN, J., INGWERSON, N. \& THOMAS, D. 2013a. Child height after a natural disaster. Duke University.

FRANKENBERG, E., FRIEDMAN, J., SIKOKI, B., SURIASTINI, W., SUMANTRI, C., \& THOMAS, D, 2007. Assessing Health and Education Services in the Aftermath of a Disaster. In: AMIN, S., DAS, J., \& GOLDSTEIN, M. , (ed.) Are you being served?: new tools for measuring service delivery. . Washington DC, USA: World Bank Publications.

FRAnkEnBERG, E., GIllesPie, T., PRESTON, S., SIKOKI, B. \& THOMAS, D. 2011. Mortality, the Family and the Indian Ocean Tsunami. Economic Journal, 121, F162-F182.

FRANKENBERG, E., NOBLES, J. \& SUMANTRI, C. 2012. Community Destruction and Traumatic Stress in Post-Tsunami Indonesia. Journal of Health and Social Behavior, 53, 498-514.

FRANKENBERG, E., SIKOKI, B., SUMANTRI, C., SURIASTINI, W. \& THOMAS, D. 2013b. Education, Vulnerability, and Resilience after a Natural Disaster. Ecology and Society, 18.GAILLARD, J.-C., CLAVÉ, E. \& KELMAN, I. 2008a. Wave of peace? Tsunami disaster diplomacy in Aceh, Indonesia. Geoforum, 39, 511-526.

FREEMAN, N. J., \& THAN, T. M. M. (Eds.). (2002). Regional Outlook: Southeast Asia 2002-2003. Institute of Southeast Asian Studies.

GAILlaRD, J.-C., CLAVÉ, E., VIBERT, O., AZHARI, DEDI, DENAIN, J.-C., EFENDI, Y., GRANCHER, D., LIAMZON, C. C., SARI, D. R. \& SETIAWAN, R. 2008b. Ethnic groups' response to the 26 December 2004 earthquake and tsunami in Aceh, Indonesia. Natural Hazards, 47, 17-38.

GERTler, P., HECKMAN, J., PINTO, R., ZANOLINI, A., VERMEERSCH, C., WALKER, S., CHANG, 
S. M. \& GRANTHAM-MCGREGOR, S. 2014. Labor market returns to an early childhood stimulation intervention in Jamaica. Science, 344, 998.

GLUCKMAn, P. D., HANSON, M. A., COOPER, C. \& THORNBURG, K. L. 2008. Effect of in utero and early-life conditions on adult health and disease. New England Journal of Medicine, 359, 61-73.

GRAY, C., FRANKEnBERG, E., GILleSPIE, T., SUMANTRI, C. \& THOMAS, D. 2014. Studying Displacement After a Disaster Using Large Scale Survey Methods: Sumatra After the 2004 Tsunami. Annals of the Association of American Geographers. Association of American Geographers, 104, 594-612.

GRAYMAN, J. H. 2014. Rapid response: email, immediacy, and medical humanitarianism in Aceh, Indonesia. Social science and medicine, 120, 334-343.GUHA-SAPIR, D., PANHUIS, W. G. V. \& LAGOUTTE, J. 2007. Patterns of chronic and acute diseases after natural disasters - a study from the International Committee of the Red Cross field hospital in Banda Aceh after the 2004 Indian Ocean tsunami. Tropical Medicine and International Health, 12, 1338-1341.

GUHA-SAPIR, D. \& VAN PANHUIS, W. G. 2009. Health Impact of the 2004 Andaman Nicobar Earthquake and Tsunami in Indonesia. Prehospital and Disaster Medicine, 24, 493-499.

GUPtA, S. K., SUANTIO, A., GRAY, A., WidyASTUti, E., JAin, N., ROLOS, R., HOEKSTRA, R. M. \& QUICK, R. 2007. FACTORS ASSOCIATED WITH E. COLI CONTAMINATION OF HOUSEHOLD DRINKING WATER AMONG TSUNAMI AND EARTHQUAKE SURVIVORS, INDONESIA. The American Journal of Tropical Medicine and Hygiene, 76, 1158-1162.

GUTIERREZ, E., TAUCER, F., DE GrOeVE, T., AL-KHUDHAIRY, D. \& ZALDIVAR, J. 2005. Analysis of worldwide earthquake mortality using multivariate demographic and seismic data. American journal of epidemiology, 161, 1151-1158.

HALLEGATTE, S., VOGT-SCHILB, A., BANGALORE, M. \& ROZENBERG, J. 2016. Unbreakable: building the resilience of the poor in the face of natural disasters, World Bank Publications.

HAYAT, E. \& AMARATUNGA, D. 2014. The Impact of the Local Political and Socio-Economic Condition to the Capacity of the Local Governments in the Maintenance of Post-Disaster Road Infrastructure Reconstruction Assets. In: AMARATUNGA, D. \& HAIGH, R. (eds.) 4th International Conference on Building Resilience, Incorporating the 3rd Annual Conference of the Android Disaster Resilience Network.

HEGER, M. 2016. The causal effects of the Indian Ocean tsunami and armed conflict on Aceh's economic development. PHD, London School of Economics.

HO, J. Y., FRANKENBERG, E., SUMANTRI, C. \& THOMAS, D. 2017. Adult Mortality Five Years after 
a Natural Disaster. Population and Development Review, 43, 467-490.

HoddinotT, J., MAluCcio, J. A., Behrman, J. R., FlORES, R. \& MARTORELL, R. 2008. The impact of nutrition during early childhood on income, hours worked, and wages of Guatemalan adults. Lancet, $371,411-416$.

ICHWAN, M. N. 2011. Official Ulema and the Politics of Re-Islamization: The Majelis Permusyawaratan Ulama, Sharī?atization and Contested Authority in Post-New Order Aceh1. Journal of Islamic Studies, 22, 183214.

IRMANSYAH, I., DHARMONO, S., MARAMIS, A. \& MINAS, H. 2010. Determinants of psychological morbidity in survivors of the earthquake and tsunami in Aceh and Nias. Int J Ment Health Syst, 4.

ISMAIL, N., SUWANNAPONG, N., HOWTEERAKUL, N., TIPAYAMONGKHOLGUL, M. \& APINUNTAVECH, S. 2016. Assessing disaster preparedness and mental health of community members in Aceh, Indonesia: a community-based, descriptive household survey of a national program. Rural and Remote Health, 16.

JAMES, E. 2006. Clean or corrupt: tsunami aid in Aceh. ANU Research Publications.

JAUHOLA, M. 2010. Building back better? - negotiating normative boundaries of gender mainstreaming and post-tsunami reconstruction in Nanggroe Aceh Darussalam, Indonesia. Review of international studies, 36, 29-50.

JAYASURIYA, S. \& MCCAWLEY, P. 2008. Reconstruction after a major disaster: Lessons from the postTsunami experience in Indonesia, Sri Lanka, and Thailand. ADBI Working Paper Series, Asian Development Bank Institute (ADBI).

JAYASURIYA, S. \& MCCAWLEY, P. 2010. The Asian Tsunami: Aid and Reconstruction after a Disaster, Cheltenham, UK, Edward Elgar Publishing Limited.

JEREMiJENKO, A., MCLAWS, M. L. \& KOSASIH, H. 2007. A tsunami related tetanus epidemic in Aceh, Indonesia. Asia-Pacific journal of public health, 19 Spec No, 40-44.

KENNY, S. 2007. Reconstruction in Aceh: building whose capacity? Community development journal, 42, 206-221.

LEE, C., DOOCY, S., DELI, A., KIRSCH, T., WEISS, W. \& ROBINSON, C. 2014. Measuring impact: a cross-sectional multi-stage cluster survey to assess the attainment of durable solutions in post-tsunami Aceh, Indonesia. BMC Public Health, 14, 1168.

LEE, C., DU, Y., CHRISTINA, D., PALFREY, J., O'ROURKE, E. \& BELFER, M. 2015. Displacement as 
a predictor of functional impairment in tsunami-exposed children. Disasters, 39, 86-107.

LOVhOLT, F., SETIADI, N. J., BIRKMAnN, J., HARBITZ, C. B., BACH, C., FERNANDO, N., KAISER, G. \& NADIM, F. 2014. Tsunami risk reduction - are we better prepared today than in 2004? International Journal of Disaster Risk Reduction, 10, 127-142.

MACCINI, S. \& YANG, D. 2009. Under the weather: Health, schooling, and economic consequences of early-life rainfall. American Economic Review, 99, 1006-26.

MAlucCiO, J. A., HODDinotT, J., BeHRMAn, J. R., MARTORELl, R., QUiSUMBING, A. R. \& STEIN, A. D. 2009. The impact of improving nutrition during early childhood on education among Guatemalan adults. The Economic Journal, 119, 734-763.

MARTHOENIS, M., YESSI, S., AICHBERGER, M. C. \& SCHOUlER-OCAK, M. 2016. Mental health in Aceh-Indonesia: A decade after the devastating tsunami 2004. Asian Journal of Psychiatry, 19, 59-65.MASSET, E. 2015. Child Mortality Rates Using Synthetic Cohort Probabilities [Online]. University of Sussex Brighton, UK. Available: http://fmwww.bc.edu/repec/bocode/s/syncmrates.sthlp.

MASYRAFAH, H. \& MCKEON, J. M. 2008. Post-Tsunami aid Effectiveness in Aceh: Proliferation and Coordination in Reconstruction. Brookings Global Economy and Development. Washington, DC: Wolfensohn Center for Development, Brookings Institution.

MCFARLANE, A. C. 1987. Posttraumatic phenomena in a longitudinal study of children following a natural disaster. Journal of the American Academy of Child \& Adolescent Psychiatry, 26, 764-769.

MCNICOLL, G. 2011. Achievers and laggards in demographic transition: A comparison of Indonesia and Nigeria. PoPulation and develoPment review, 37, 191-214.

MEILIANDA, E., MUNADI, K., AZMERI, SAFRIDA, DIREZKIA, Y., SYAMSIDIK, OKTARI, R. S. \& IOP. Assessment of post-tsunami disaster recovery of Banda Aceh city of Indonesia as window of opportunities for sustainable development. 10th Aceh International Workshop and Expo on Sustainable Tsunami Disaster Recovery, 2017.

MuldoOn, K. A., GAlWAY, L. P., NAKAJIMA, M., KANTERS, S., HOGG, R. S., BENDAVID, E. \& MILLS, E. J. 2011. Health system determinants of infant, child and maternal mortality: A cross-sectional study of UN member countries. Globalization and health, 7, 42 .

MURIUKI, D., HAHN, S., HEXOM, B. \& ALLAN, R. 2012. Cross-sectional survey of malaria prevalence in tsunami-affected districts of Aceh Province, Indonesia. International Journal of Emergency Medicine, 5 (??) (no pagination). 
NAKAGAWA, I., NAKAMURA, K., OYAMA, M., YAMAZAKI, O., ISHIGAMI, K., TSUCHIYA, Y. \& YAMAMOTO, M. 2009. Long-term effects of the Niigata-Chuetsu earthquake in Japan on acute myocardial infarction mortality: an analysis of death certificate data. Heart, 95, 2009.

NEELSEN, S. \& STRATMANN, T. 2011. Effects of prenatal and early life malnutrition: Evidence from the Greek famine. Journal of Health Economics, 30, 479-488.

NOBLES, J., FRANKENBERG, E. \& THOMAS, D. 2015. The Effects of Mortality on Fertility: Population Dynamics After a Natural Disaster. Demography, 52, 15-38.

OKTARI, R. S., FAHLEVI, H., IRAWATI, W. \& IOP 2017. Disaster budgeting of Banda Aceh's local government: Trends and analysis of post-tsunami Aceh 2004. 10th Aceh International Workshop and Expo on Sustainable Tsunami Disaster Recovery.

PASCAPURnAmA, D. N., MURAKAMi, A., CHAGAN-YASUTAN, H., HATTORI, T., SASAKI, H. \& EGAWA, S. 2016. Prevention of Tetanus Outbreak Following Natural Disaster in Indonesia: Lessons Learned from Previous Disasters. Tohoku Journal of Experimental Medicine, 238, 219-227.

PATUnRU, A. A. 2015. Access to Safe Drinking Water and Sanitation in Indonesia. Asia \& the Pacific Policy Studies, 2, 234-244.

PFEFFERBAUM, B. 1997. Posttraumatic stress disorder in children: A review of the past 10 years. Journal of the American Academy of Child \& Adolescent Psychiatry, 36, 1503-1511.

PHElPS, N. A., BUNnell, T. \& MilleR, M. A. 2011. Post-disaster economic development in Aceh: Neoliberalization and other economic-geographical imaginaries. Geoforum, 42, 418-426.

POWELL-JACKSON, T., MAZUMDAR, S., \& MILlS, A. (2015). Financial incentives in health: New evidence from India's Janani Suraksha Yojana. Journal of health economics, 43, 154-169.

PRASETIYAWAN, VIORA, E., MARAMIS, A. \& KELIAT, B. A. 2006. Mental health model of care programmes after the tsunami in Aceh, Indonesia. International Review of Psychiatry, 18, 559-562.

RASSEKH, B. M. \& SANTOSHAM, M. 2014. Utilization of formal health services for children aged 1-5 in Aceh after the 2004 tsunami: Which children did not receive the health care they needed? Implications for other natural disaster relief efforts. Health Psychology and Behavioral Medicine, 2, 111-131.

REDWOOD-CAMPBELL, L. J. \& RIDDEZ, L. 2012. Post-Tsunami Medical Care: Health Problems Encountered in the International Committee of the Red Cross Hospital in Banda Aceh, Indonesia. Prehospital and Disaster Medicine, 21, S1-S7. 
RÉGNIER, P., NERI, B., SCUTERI, S. \& MINIATI, S. 2008. From emergency relief to livelihood recovery: Lessons learned from tsunami experiences in Indonesia and India. Disaster Prevention and Management: An International Journal, 17, 410-430.ROFI, A., DOOCY, S. \& ROBINSON, C. 2006. Tsunami mortality and displacement in Aceh province, Indonesia. Disasters, 30, 340-350.

SCHWAB, F. D., ZETTler, E. K., MOH, A., SCHOtZAU, A., GROSS, U. \& GUNTHERT, A. R. 2016. Predictive factors for preterm delivery under rural conditions in post-tsunami Banda Aceh. Journal of Perinatal Medicine, 44, 511-515.

SHAH, R. \& CARDOZO, M. L. 2014. Education and social change in post-conflict and post-disaster Aceh, Indonesia. International Journal of Educational Development, 38, 2-12.SMITH, C. 2015. Doctors that Harm, Doctors that Heal: Reimagining Medicine in Post-Conflict Aceh, Indonesia. Ethnos, 80, 272-291.

SRINIVAS, H. \& NAKAGAWA, Y. 2008. Environmental implications for disaster preparedness: lessons learnt from the Indian Ocean tsunami. Journal of environmental management, 89, 4-13.

STEINBERG, F. 2007. Housing reconstruction and rehabilitation in Aceh and Nias, Indonesia - rebuilding lives. Habitat international, 31, 150-166.

Sudomo, M., ARIANTI, Y., WAHID, I., SAFruddin, D., PEDERSEN, E. M. \& CHARLWOOD, J. D. 2010. Towards eradication: three years after the tsunami of 2004, has malaria transmission been eliminated from the island of Simeulue? Transactions of the Royal Society of Tropical Medicine and Hygiene, 104, 777-781.

SYAMSIDIK, RUSYDY, I., ARIEF, S., MUNADI, K., MELIANDA, E. \& IOP 2017. Disaster risk reduction policies and regulations in Aceh after the 2004 Indian Ocean Tsunami. 10th Aceh International Workshop and Expo on Sustainable Tsunami Disaster Recovery.

THORBURN, C. 2009. Livelihood recovery in the wake of the tsunami in Aceh. Bulletin of Indonesian economic studies, 45, 85-105.

ThORMAR, S. B., GERSOns, B. P. R., JuEn, B., DJAKABABA, M. N., KARLSSON, T. \& OLFF, M. 2014. The impact of disaster work on community volunteers: The role of pen-traumatic distress, level of personal affectedness, sleep quality and resource loss, on post-traumatic stress disorder symptoms and subjective health. Journal of Anxiety Disorders, 28, 971-977.

URlAinis, A., SHOHET, I. M., LEVY, R., ORNAI, D. \& VILNAY, O. 2014. Damage in critical infrastructures due to natural and man-made extreme events A critical review. In: HAJDU, M. \& SKIBNIEWSKI, M. J. (eds.) Creative Construction Conference 2014. 
USCHER-PINES, L. 2009. Health effects of relocation following disaster: a systematic review of the literature. Disasters, 33, 1-22.

WAIZENEGGER, A. \& HYNDMAN, J. 2010. Two solitudes: post-tsunami and post-conflict Aceh. Disasters, $34,787-808$.

WALKER, S. P., CHANG, S. M., POWELL, C. A. \& GRANTHAM-MCGREGOR, S. M. 2005. Effects of early childhood psychosocial stimulation and nutritional supplementation on cognition and education in growthstunted Jamaican children: prospective cohort study. The lancet, 366, 1804-1807.

WEBB, P. 2005. Food and nutrition concerns in Aceh after the tsunami. Food and Nutrition Bulletin, 26, 393-396.WORLD BANK 2005. Indonesia: preliminary damage and loss assessment- The December 26, 2004 natural disaster. Washington, DC: World Bank.

WORLD BANK 2009a. Aceh Economic Update (May 2009). Washington, DC: World Bank. http: //documents. worldbank.org/curated/en/547781468268829286/Aceh-economic-update-May-2009.

WORLD BANK 2009b. Multi-stakeholder review of post-conflict programming in Aceh : identifying the foundations for sustainable peace and development in Aceh. 2.

WORLD BANK 2015. Indonesia Database for Policy and Economic Research. 8 June 2015 ed.

WORLD HEALTH ORGANIZATION. 2005. Tsunami recovery process focuses on long-term health capacity development [Online]. Available: http://www.who.int/mediacentre/news/releases/2005/pr30_searo/en/.

WORLD HEALTH ORGANIZATION 2015. Ten Years After the Tsunami of 2004: Impact Action Change Future.

WORLD HEALTh ORGAniZATION 2017. The Republic of Indonesia Health System Review. Asia Pacific Observatory on Health Systems and Policies

WORLDWATCH INSTITUTE. 2006. Aceh: Peacemaking after the Tsunami [Online]. Available: http: //www . worldwatch.org/node/3930. [Accessed 10 July 2017].

YEHUDA, R. 2002. Post-traumatic stress disorder. New England journal of medicine, 346, 108-114.

ZECCOLA, P. 2011. Dividing disasters in Aceh, Indonesia: separatist conflict and tsunami, human rights and humanitarianism. Disasters, 35, 308-328. 